\title{
Geomicrobial functional groups: A window on the interaction between life and environments
}

\author{
XIE ShuCheng ${ }^{1 *}$, YANG Huan ${ }^{1}$, LUO GenMing ${ }^{2}$, HUANG XianYu ${ }^{2}$, LIU Deng ${ }^{1}$, \\ WANG YongBiao ${ }^{2}$, GONG YiMing ${ }^{1} \&$ XU Ran ${ }^{1}$ \\ ${ }^{1}$ State Key Laboratory of Biogeology and Environmental Geology, China University of Geosciences, Wuhan 430074, China; \\ ${ }^{2}$ State Key Laboratory of Geological Processes and Mineral Resources, China University of Geosciences, Wuhan 430074, China
}

Received August 1, 2011; accepted October 24, 2011

\begin{abstract}
Microbes are well-known for their great diversity and abundance in modern natural environments. They also are believed to provide critical links among higher organisms and their associated environments. However, the low diversity of morphological features and structures of ancient microbes preserved in sediments and rocks make them difficult to identify and classify. This difficulty greatly hinders the investigation of geomicrobes throughout Earth history. Thus, most previous paleontological studies have focused on faunal and floral fossils. Here, geomicrobial functional groups (GFGs), or a collection of microbes featured in specific ecological, physiological or biogeochemical functions, are suggested to provide a way to overcome the difficulties of ancient microbe investigations. GFGs are known for their great diversity in ecological, physiological and biogeochemical functions. In addition, GFGs may be preserved as the biogeochemical, mineralogical and sedimentological records in sediments and rocks. We reviewed the functions, origins and identification diagnostics of some important GFGs involved in the elemental cycles of carbon, sulfur, nitrogen and iron. GFGs were further discussed with respect to their significant impacts on paleoclimate, sulfur chemistry of ancient seawater, nutritional status of geological environments, and the deposition of Precambrian banded iron formations.
\end{abstract}

geomicrobial functional group, carbon-sulfur-nitrogen cycle, iron reduction and oxidation, photosynthesis, molecular fossils, geobiology, critical periods

Citation: Xie S C, Yang H, Luo G M, et al. Geomicrobial functional groups: A window on the interaction between life and environments. Chin Sci Bull, 2012, 57: 2-19, doi: 10.1007/s11434-011-4860-x

It is not straightforward to fully understand all the dynamic processes of major environmental changes throughout the evolution of Earth. However, it is critical to understand the interactions between life and environments during major environmental transitions throughout history. Previous work has focused on environmental impacts on the biosphere, with assumptions made that organisms can only passively adapt to environmental changes. For example, major and rapid volcanic eruptions as a result of mantle plume dynamic processes have been proposed to trigger a series of variations in both the atmosphere and marine environments, which have resulted in major impacts on biosphere evolution [1]. It is notable that the biosphere also alters the phys-

*Corresponding author (email: xiecug@163.com) ical and chemical conditions of the Earth's surface system [2-4]. However, less work has been conducted concerning the positive biotic roles played in changing environments. This lack of work greatly prevents us from comprehensively understanding abrupt environmental changes throughout Earth history, as well as the evolution of the Earth as a planet.

Deciphering of positive biotic roles in environments awaits a breakthrough in research on microbial processes in ancient times [4]. Microbes include all bacteria and archaea, as well as a great majority of eukaryotes. However, only a small proportion of eukaryotes have been targeted in past paleontological investigations, leaving the majority of microbes unknown. Within an ecosystem, microbes not only affect fauna and flora, but also the natural environments in 
which these organisms live. Microbes are both producers and decomposers, which impact geological environments via energy flow and material cycles [5]. In this regard, microbial processes are suggested to be one of the critical components in changing the Earth's system in both ancient and modern times. Nevertheless, less is known with regard to geomicrobial roles over geological times. This is partly, if not entirely due to the fact that most geomicrobes preserved in rocks show less diagnostic morphological and structural features, and cannot always be identified and classified to a specific taxon on the basis of the morphological investigations.

It is important to establish strategies to resolve these identification difficulties. Although geomicrobes are not always easy to assign to a specific genus or species, it is the functional groups of the geomicrobes that play a dominant role in most geological processes [6,7]. This implies that geomicrobial functional groups (GFGs) directly interact with natural environments. GFGs are defined as a collection of microbes featured in specific ecological, physiological or biogeochemical functions, such as the well-known nitrogen-fixing functional group. GFGs are entirely different from taxonomic groups, in that they show a close link between functions and associated environments. Thus, it is necessary to focus our investigations on the GFGs among diverse geomicrobes, in particular those capable of metabolizing the chemical species of carbon, nitrogen, sulfur and iron. Furthermore, GFGs link microbial ecology with biogeochemical processes $[6,8]$, providing a unique opportunity to allow preservation of microbial fingerprints in rocks and sediments as the records of molecular fossils, diverse geochemical records, microbial minerals, and microbiallyinduced sedimentary structures. These records, recovered by advanced isotope techniques and micro-analysis, provide the micro- and macro-indicators for geological processes induced by geomicrobes. Previously, it was difficult to identify specific GFGs preserved in rocks because of poor analytical techniques. These problems are likely to be overcome with recent analytical advances to investigate GFGs and their roles in diverse geological processes. Here, we mainly review some important GFGs closely involved in the biogeochemical cycles of carbon, sulfur, nitrogen and iron, and evaluate the function, origin, identification diagnostics, and roles of these GFGs in changing environments.

\section{Functions and origins of some critical GFGs}

\subsection{Photosynthetic GFGs}

Anoxygenic and oxygenic photosynthesis are important metabolic pathways. The emergence of photosynthetic GFGs was a milestone in the evolution of life, and provided more energy sources for carbon fixation [9]. The earliest photosynthetic microbes belong to the domain bacteria, and include halobacteria, purple sulfur bacteria, purple non- sulfur bacteria, green sulfur bacteria, green non-sulfur bacteria, heliobacteria and cyanobacteria. Among these microbes, cyanobacteria are the only chlorophyll-containing photosynthetic bacteria, and thus the only oxygenic photosynthetic GFGs. Eukaryotes have been shown to have inherited oxygenic photosynthesis from endosymbiosis with cyanobacteria [10].

The origin of photosynthetic microbes is an important scientific issue to be investigated. Here, we provide a brief summary. More relevant information can be found in the literature [11-14]. Evidence from geochemical, molecular biological and paleontological investigations indicates that photosynthesis is an ancient metabolic pathway [14]. Anoxygenic photosynthetic microbes appear to have had a much earlier origin than oxygenic photosynthetic microbes. Based on molecular studies, purple sulfur bacteria may be the oldest of such microbes [15]. The early Earth had a reductive atmosphere and oceans, where photosynthesis was predominantly anoxygenic, using $\mathrm{H}_{2}, \mathrm{~S}, \mathrm{H}_{2} \mathrm{~S}$ and $\mathrm{Fe}^{2+}$ as electron donors [14]. Photosynthesis using $\mathrm{Fe}^{2+}$ as the electron donor is believed to have already been prevalent long before the appearance of oxygenic photosynthesis. Early cyanobacteria also are suggested to have used $\mathrm{Fe}^{2+}$ as the electron donor during photosynthesis [13]. This pathway has been suggested to be one of the mechanisms responsible for production of Precambrian banded iron formations (BIF) [16-19].

The origin of oxygenic photosynthesis is a critically important part of the evolutionary history of life, yet it is still highly debated [12]. Several lines of geochemical evidence indicate the presence of a great oxidation event about 2.4 billion years ago [20] or a transient oxidation event a little before that time [21-23]. This provides the minimum age for oxygenic photosynthesis. Currently, three different viewpoints have been put forth regarding the origination time of the oxygenic photosynthesis. Some scientists believe that oxygenic photosynthesis originated several hundred million years earlier than the first great oxidation event [24]. This is because quite a long time period is needed to allow the oxygen produced by oxygenic photosynthesis to oxidize volcanic reductive gases, hydrothermal fluids and minerals, which enabled the occurrence of the subsequent great oxidation event. Other scientists believe that oxygenic photosynthesis was almost synchronous with the first great oxidation event [25]. Furthermore, other researchers tend to believe that oxygenic photosynthesis appeared much earlier than any geological records reported on the Earth, which allows the possibility for the presence of a highly oxidative atmosphere in the Archean [26]. Diverse records of biogeochemistry, sedimentology, mineralogy and paleontology are further required to precisely constrain the origination time of oxygenic photosynthesis.

Algae originated much later than photosynthetic bacteria. Chlorophyta became important primary producers in the late Proterozoic, while dinoflagellates, coccoliths and dia- 
toms did not become important primary producers on the continental shelf until the Mesozoic Era [27].

\subsection{GFGs in methane cycling}

Terrestrial plant ecosystems are believed to have a great impact on global climate change via regulation of the carbon cycle, which can now be quantitatively evaluated by mathematical modeling. However, GFGs also can play very important roles, by not only producing and consuming $\mathrm{CO}_{2}$ and $\mathrm{CH}_{4}$, but also degrading organic matter. Both of these processes dramatically affect carbon sources, sinks and fluxes, and thus regulate the global carbon cycle. For example, methanogens and methanotrophs have been demonstrated to dominantly affect atmospheric $\mathrm{CH}_{4}$ concentration. In the marine environment, some bacteria, such as aerobic anoxygenic phototrophic bacteria, can transfer bioavailable dissolved organics to recalcitrant dissolved organics, favoring their accumulation in seawater over a long period of time [28]. Great attention has been placed in deciphering the relationship between atmospheric $\mathrm{CH}_{4}$ concentration and paleoclimate change throughout Earth history. This is because $\mathrm{CH}_{4}$ is the second most important greenhouse gas, and has a relatively depleted carbon isotopic composition in the geological record. Here, we summarize the general features of $\mathrm{CH}_{4}$-associated GFGs, mainly methanogens and methanotrophs.

Methanogens are obligate anaerobic and autotrophic archaea, widely occurring in anoxic conditions in a variety of extreme environments, including marine environments $[29,30]$, as well as wetlands, and in particular peatlands $[31,32]$. The biosynthesis of $\mathrm{CH}_{4}$ by methanogens includes the pathways involving acetate, $\mathrm{H}_{2} / \mathrm{CO}_{2}$ and methyl compounds. High $\mathrm{CH}_{4}$ level has been previously observed over neotropic forests throughout the world, and is now explained by the presence of a diverse community of $\mathrm{CH}_{4}$-producing archaea. These archaea have been found to multiply in the canopy of belled mouth bromeliads, which enable rainfall to accumulate and form an environment analogous to wetlands [33]. Other potential wet parts in trees (e.g. hollow bamboo internodes, tree holes, nonbromeliad leaf axils) also have been suggested to provide an additional contribution to $\mathrm{CH}_{4}$ in tropical and subtropical forests.

In contrast to methanogens, which biosynthesize $\mathrm{CH}_{4}$, the methanotrophs from both bacteria and archaea domains consume $\mathrm{CH}_{4}$. In deep sea environments, such as in hydrothermal vents and cold seeps, a consortia of anaerobic methane oxidation archaea and sulfate-reducing bacteria complete the anaerobic oxidation of $\mathrm{CH}_{4}[34,35]$. To date, the dynamic mechanisms of anaerobic $\mathrm{CH}_{4}$ oxidation are still debated. A pathway reversing methanogensis in methanogens is widely accepted with respect to consumption of $\mathrm{CH}_{4}$ and production of cellular carbon and energy [36]. In freshwater conditions, $\mathrm{CH}_{4}$-consuming archaea anaerobi- cally oxidize $\mathrm{CH}_{4}$ by coupling with the denitrification process [37]. Recently, Ettwig et al. [38] isolated an anaerobic bacterium from freshwater, which can produce oxygen and oxidize $\mathrm{CH}_{4}$ by using the oxygen produced. This oxygen-producing pathway has great biogeochemical and evolutionary implications.

In peatlands, most biotic oxidation of $\mathrm{CH}_{4}$ is conducted by aerobic bacteria. In aerobic conditions, $\mathrm{CH}_{4}$ is transformed to methanal, and then used to biosynthesize organic matter via serine or RuMP pathways. The $\mathrm{CH}_{4}$-oxidizing bacteria are divided into three types on the basis of morphology, $\mathrm{G}+\mathrm{C}$ content, metabolic pathways, membrane structure and phospholipid fatty acids. Type I, belonging to the $\gamma$-proteobacteria, assimilate $\mathrm{CH}_{4}$ to form methanal via RuMP pathways. Type II $\mathrm{CH}_{4}$-oxidizing bacteria include $\alpha$-protebacteria, which assimilate $\mathrm{CH}_{4}$ via serine pathways. Type $\mathrm{X} \mathrm{CH}_{4}$-oxidizing bacteria fall into the Phylum Verrucomicrobia, and they synthesize methanal mainly via RuMP pathways with a very small part of the serine pathway [39].

\subsection{GFGs in sulfur cycling}

Microbial metabolism within sulfophilic species is one of the main pathways for early organisms to have harvested energy. Barophilic bacteria and archaea, the microbes presumably affiliated with the earliest common ancestor, also obtain energy through sulfur metabolism [40]. Thus, exploring microbes that metabolize sulfur species allows for a better understanding of the origin and evolution of life on Earth and possible exo-life. Sulfate and elemental sulfur reduction, disproportionation of intermediate sulfur compounds and elemental sulfur, and anaerobic and aerobic oxidation of elemental sulfur are the main microbial metabolisms in sulfur cycling. The GFGs metabolizing elemental sulfur and sulfur compounds include sulfate-reducing bacteria and archaea, sulfur-reducing bacteria and archaea, intermediate sulfur disproportionation bacteria, anaerobic sulfur-oxidizing bacteria and aerobic sulfur-oxidizing bacteria (Figure 1).

Sulfate-reducing microbes are dominated by bacteria, with only a few known archaea, both of which are obligatory anaerobic. $\delta$-protobacteria (Gram-negative bacteria) are the main sulfate-reducing bacteria, with a few Gram-positive bacteria and thermophilic bacteria (Thermodesulfobacterium and Thermodesulfovibrio) [41]. There are very few sulfate-reducing archaea found to date, and these are mostly high-temperature hot spring archaea (Archaeoglobus) [41]. Based on sulfur isotope records, the origin of sulfatereducing microbes is estimated to be as early as $3.47 \mathrm{Ga}$ $[42,43]$. It is as yet unclear whether these early sulfatereducing microbes were bacteria or archaea, although they are assumed to have been bacteria. The sulfur isotope fractionation by sulfate-reducing archaea remains uncertain [44].

Intermediate sulfur disproportionation bacteria are 


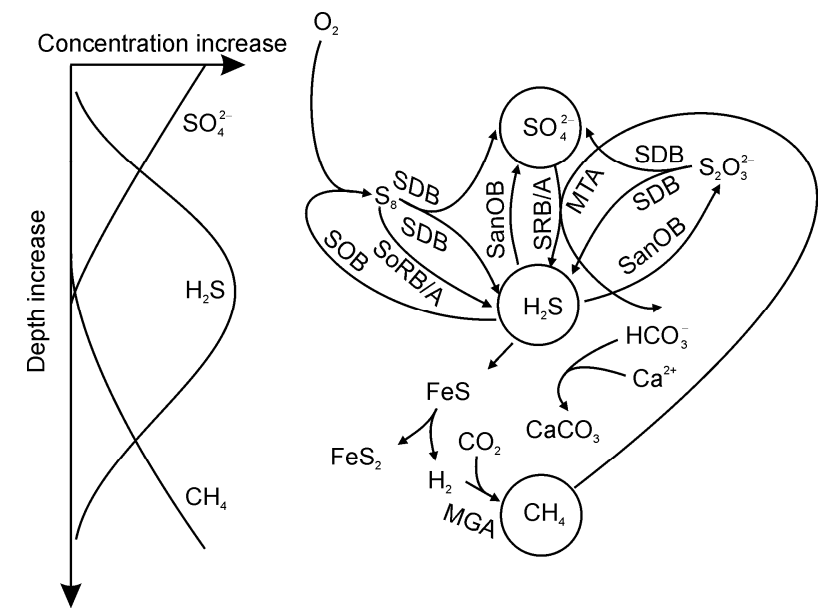

Figure 1 Sulfur cycle and the involved GFGs. SRB/A, sulfate-reducing bacteria/archaea; SDB, sulfur disproportional bacteria; SanOB, anaerobic sulfur-oxidizing bacteria; SOB, aerobic sulfur-oxidizing bacteria; SoRB/A, sulfur-reducing bacteria/archaea; MGA, methanogenic archaea; MTA, methanotrophic archaea.

anaerobic and autotrophic [45]. These bacteria can produce, via metabolism, a large sulfur isotope fractionation $\left(\Delta^{34} \mathrm{~S}>\right.$ $46 \%$ ) [46]. Based on multiple-sulfur isotopic compositions, Johnston et al. [47] postulated that these bacteria would have been present in the Mid-Mesoproterozoic, about 1.3 Ga. Parnell et al. [48] documented a very large (greater than $50 \%$ ) sulfur isotope fractionation in some terrestrial strata deposited about $1.18 \mathrm{Ga}$. They suggested this fractionation was evidence for sulfur disproportionation reduction driven by elevated atmospheric $\mathrm{O}_{2}$ content at that time. However, micro-analysis on multiple-sulfur isotopes resulted in the hypothesis that microbial sulfate reduction and sulfur disproportionation would have existed about $3.4 \mathrm{Ga}$ [49]. It is notable that microbial sulfate reduction itself also can induce very large sulfur isotopic fractionation [50-52]. All of these data appear to be contradictory with the proposal that sulfur disproportion is indicative of elevated content of atmospheric $\mathrm{O}_{2}$ [53].

Anaerobic sulfur-oxidizing bacteria mainly include green sulfur bacteria and purple sulfur bacteria living in the euxinic photic zone, both of which are anoxygenic and photoautotrophic. They can utilize sunlight as an energy source and $\mathrm{H}_{2} \mathrm{~S}$ as an electron donor for $\mathrm{CO}_{2}$ fixation. The origination of these microbes was thought to be no later than 1.6 Ga [54]. However, they are scarcely found in Precambrian rocks, but show a frequent occurrence in Phanerozoic anoxic environments [55]. This differentiation may have been caused by high maturity of organic matter in Precambrian rocks, which may have destroyed the diagnostic compounds of these microbes. The low sulfate concentration in Precambrian oceans also may have inhibited the bloom of these microbes.

Aerobic sulfur-oxidizing bacteria generally require $\mathrm{O}_{2}$ to oxidize elemental sulfur, and are believed to have originated later in Earth history. Biomarkers and paleontological rec- ords suggest that these aerobic bacteria existed in the ocean about $1.64 \mathrm{Ga}$ [56]. However, these GFGs may not have needed molecular oxygen, and could have an earlier origin. For example, aerobic sulfur-oxidizing bacteria have been found in $\mathrm{H}_{2} \mathrm{~S}$-bearing waters below the chemocline in the modern Black Sea [57]. Some studies have shown that these GFGs can use nitrate to replace $\mathrm{O}_{2}$ as the electron donor during the microbial oxidization of sulfur [58]. Wacey et al. [59] suggested that these GFGs may have existed in the ocean about 3.4 billion years ago.

Sulfur-reducing metabolism is also ancient, but has a low energy yield [41]. Microbes involved in this metabolism include bacteria and archaea, most of which are anaerobic heterotrophic microbes [41]. In addition to sulfur, some oxides, such as the oxides of manganese (IV) and iron (III) [41] can be reduced by these microbes. The sulfur-reducing archaea discovered to date are extremely thermophilic microbes in hot spring systems. Little is known about the origin and evolution of these archaea.

It is clear that all the sulfur-metabolizing GFGs appeared early in Earth history (Early Archean). However, it is still not clear what the causes of their early occurrence may have been, and what is the geological implication. More work is needed to decipher these issues, in particular, investigation of microbial lipids, their compound-specific isotope composition and functional genes of modern analogs.

\subsection{GFGs in nitrogen cycling}

Nitrogen is more important than phosphorous as an element to determine marine primary productivity [60]. Microbes act as a powerful engine to drive the nitrogen cycle in the global ecological systems, and play significant roles in the transformation of different nitrogen species $\left(\mathrm{NH}_{4}^{+}, \mathrm{NO}_{3}^{-}\right.$and $\mathrm{N}_{2}$, etc., Figure 2) [8].

Nitrogen gas cannot be used directly by most organisms. However, nitrogen-fixing microorganisms can convert nitrogen gas into bio-available ammonia, the fundamental constituents for the biosynthesis of proteins and nucleic acids [8]. The nitrogen-fixing microbial functional group differs significantly in marine and terrestrial environments. The diazotrophic microorganisms in open oceans are primarily from the cyanobacterium genus Trichodesmium. However, some unicellular cyanobacteria (e.g. Crocosphaera watsonii) have been discovered recently in the oligotrophic regions of open oceans at high latitudes and deep waters, with both biomass and nitrogen-fixing rate comparable with those of Trichodesmium. These widely-distributed unicellular cyanobacteria have made a major contribution to the marine nitrogen budget, and have become important organisms to help understand the marine nitrogen cycle [61]. Cyanobacterial nitrogen-fixation is primarily regulated by the nif $\mathrm{H}$ gene [62], which can encode the key protein, iron and molybdenum nitrogenase. The bioavailability of metals, such as iron and molybdenum can, 


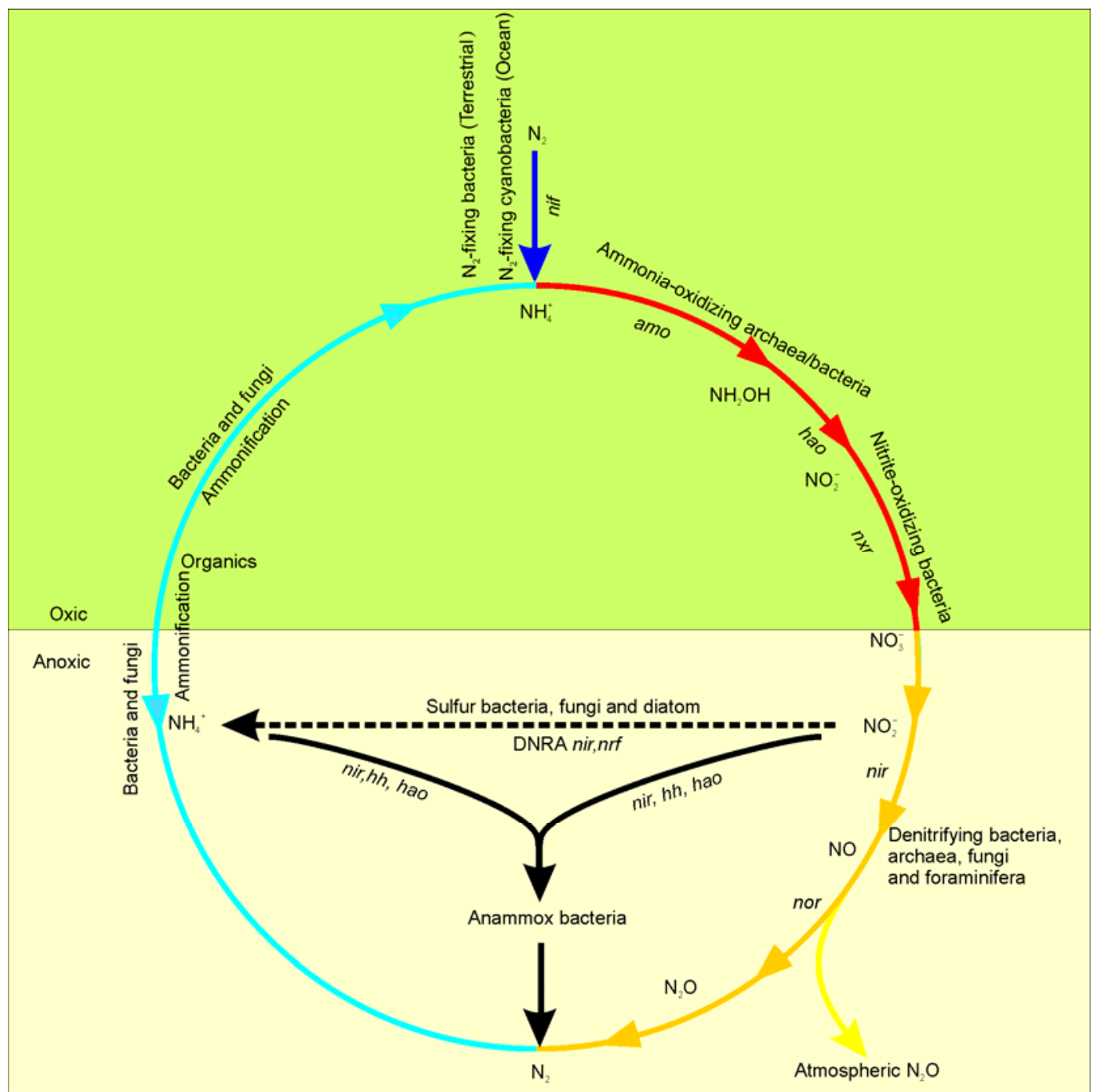

Figure 2 Nitrogen cycle and the related GFGs. nif, nitrogenase; amo, ammonia monooxygenase; hao, hydroxyl-amine oxidoreductase; nxr, nitrite oxidoreductase; $h h$, hydrazine hydrolase; nor, NO reductase. The purple, red, yellow, blue and black lines or curves denote, respectively, the nitrogen-fixing process, nitrification, denitrification, ammonification and anommox processes. The dashed line represents dissimilatory nitrate reduction to ammonium.

to some extent, affect microbial nitrogen-fixing processes [63]. In terrestrial environments, the primary diazotrophic microorganisms are rhizobia and some free-living nitrogen-fixing bacteria and archaea. In modern microbial mats, cyanobacteria and $\gamma$-proteobacteria can co-occur in the same microbial community, and collectively constitute the $\mathrm{N}_{2}$-fixing GFGs. Nevertheless, the primary nitrogen- fixation in these microbial mats is regulated by different microbes at different time. Cyanobacteria primarily fix nitrogen from day time to midnight, whereas $\gamma$-proteobac- teria become the dominant nitrogen-fixer from midnight to dawn [64].

Biologically fixed ammonia can be consumed by organisms or further oxidized to nitrate by ammonia-oxidizing GFGs (Figure 2). The ammonia oxidizers were first believed to be obligatory aerobic and chemolithotrophic ammonia-oxidizing bacteria (AOB), phylogenetically within $\beta$ and $\gamma$-proteobacteria [65]. However, Leininger et al. [66] found that on the basis of quantitative Q-PCR measurement of the ammonia monooxygenase gene (amoA; key gene regulating ammonia-oxidation), ammonia-oxidizing archaea (AOA) were clearly more abundant than AOB in modern soils. AOA also were found to dominate over AOB in most other environments, including marine or lacustrine water columns and sediments [67]. AOA are phylogenetically affiliated with Crenarchaeota group 1.1. They are aerobic and chemolithotrophic, and fix carbon dioxide via acetyl/ propionyl-coenzyme A carboxylase [68,69]. AOA occur in a variety of environments in great abundance, implying that they play an important role in the global nitrogen cycle. The purely cultured strains of AOA can maintain a high ammonia oxidation rate comparable with the AOA in the oligotrophic regions of open oceans, and have a remarkably high affinity to reduced nitrogen. This indicates that AOA can compete over heterotrophs and algae in oligotrophic environments by the preferential acquisition of ammonia [70]. 
Nitrification rates of $\mathrm{AOA}$ and $\mathrm{AOB}$ can be influenced by environmental conditions (e.g. pH). In acidified oceans, ammonia oxidation rates can slow down [71], and may thereby result in a fluctuating marine nitrogen pool, which also is observed in past Earth conditions, when the atmospheric $\mathrm{PCO}_{2}$ was relatively high.

To date, no microorganism has been demonstrated to be capable of directly oxidizing ammonium to nitrate. The nitrification process usually includes two steps; AOA or AOB first transform ammonium to nitrite, and then nitriteoxidizing bacteria further oxidize nitrite into bio-accessible nitrate. Different from nitrification, denitrification can be triggered by bacteria, archaea or fungi. Even some benthic foraminifera have been demonstrated to perform the complete denitrification process from nitrate to nitrogen gas [72]. Denitrifiers are generally facultatively anaerobic heterotrophs, and use nitrate as the final electron acceptor. $\mathrm{NO}_{3}^{-}$ reduction during denitrification is catalyzed by nitrite reductase (nir) and NO reductase (nor) with the intermediate product of $\mathrm{N}_{2} \mathrm{O}$, a kind of greenhouse gas. The atmospheric $\mathrm{N}_{2} \mathrm{O}$ concentration has been found to be usually greater in interglacial periods than in glacial periods, suggesting that the denitrification process possibly exerts an impact on global climate change via $\mathrm{N}_{2} \mathrm{O}$ emission [60]. Nitrification and denitrification can balance the dynamics of the global nitrogen cycle. However, an estimate of nitrogen budget reveals that nitrogen loss is clearly greater than nitrogen inputs in modern marine environments [73]. In addition to denitrification, anammox, a process that converts ammonium and nitrite into nitrogen gas [74], may contribute $30 \%-50 \%$ of the nitrogen loss. The anammox bacteria, phylogenetically falling into Planctomycetes, are characterized by slow growth, but a diverse occurrence in anoxic marine or lacustrine environments or even high-temperature petroleum reservoirs [75,76]. In-depth investigations of anammox bacteria will re-shape our understanding of the nitrogen cycle throughout Earth history.

The origin of nitrogen-cycling GFGs has not yet been understood well. Oxygen may play a critical role in the origin and evolution of these GFGs. The nitrogenase genes are common in bacteria and archaea, but nitrogenase can be inactivated by free oxygen. The early anaerobic microbes capable of nitrogen-fixation may be located at the root of the phylogenetic tree, and occur before the great oxygenation events (ca. 2.4 Ga ago) [20,77]. After molecular oxygen accumulated in the atmosphere and oceans, the nitrogen-fixing microbes were able to develop a number of special strategies (e.g. heterocyst and photosystem I) to separate nitrogenase from free oxygen [78]. In the early evolution of Earth, the scarcity of nitrate and ammonium may have triggered a selection pressure, favoring the evolution of nitrogenase in anaerobic microorganisms (e.g. methanogens, green sulfur bacteria and purple sulfur bacteria) to balance the nitrogen budget $[79,80]$. AOB and AOA use molecular oxygen to oxidize ammonium, whereas denitrifi- cation and anammox require nitrate produced in nitrification. It was not until the presence of oxygenic photosynthetic microorganisms, such as cyanobacteria, that these nitrogencycling GFGs could originate and establish the framework of the modern nitrogen cycle. In fact, $\delta^{15} \mathrm{~N}$ in sedimentary kerogen reveals that nitrification and denitrification may have occurred in the late Archaean (ca. 2.72 Ga) [81].

Another important environmental factor influencing the origin and evolution of nitrogen-cycling GFGs is the concentration of some metals (e.g. iron and molybdenum) in marine oceans. Iron and molybdenum are the fundamental elements in nitrogenase, and can be more efficient than other substitutions, such as vanadium and nickel. They also can act as clear indicators of marine redox conditions in the early history of the Earth [82]. In reduced Archean oceans, a large amount of $\mathrm{Fe}^{2+}$ may have existed in seawater, but the reduced species of molybdenum can only be trapped in sediments, where they are not be available to organisms. In the sulfidic Proterozoic oceans, iron appears to have been depleted in seawater but Mo had a relatively high content at that time, relative to Archean oceans. The oxic seawater in Phanerozoic oceans may have freed enough molybdenum, but still may show a depletion of iron [83]. The effective Fe/Mo nitrogenase only could occur at ca. $0.5-0.6 \mathrm{Ga}$, when deep ocean water was oxic and more molybdenum in oxidized form could have been released to seawater. Thereafter, the marine nitrogen cycle was significantly accelerated.

\subsection{GFGs in iron cycling}

It is well recognized that iron plays a fundamental role in microbial metabolism. Acting as an essential element, iron can be acquired by microbial cells to constitute a versatile family of cytochrome hemes, the metalloenzymes catalyzing various oxidative reactions. Iron also can be used to form intracellular minerals by magnetotactic bacteria $[84,85]$. These nano-scale minerals, generally termed magnetosomes, benefit the mobility of magnetotactic bacteria aligned along geomagnetic field lines [84,85]. Conversely, some microorganisms obtain energy by triggering the external iron redox cycle, in which ferrous iron is used as an electron donor and ferric iron as an electron acceptor.

A variety of microbes are intimately involved in $\mathrm{Fe}(\mathrm{II})$ $\mathrm{Fe}(\mathrm{III})$ redox conversions (Figure 3 ). Under conditions with nearly neutral $\mathrm{pH}, \mathrm{Fe}(\mathrm{II})$ easily can be oxidized to $\mathrm{Fe}(\mathrm{III})$ in the presence of free oxygen. However, in plant rhizosphere and hydrothermal vents, the bacteria mainly are from three genera (Gallionella, Leptothrix and Matinobacter), and can enzymaticlly oxidize $\mathrm{Fe}(\mathrm{II})$ through the following reaction, $2 \mathrm{Fe}(\mathrm{II})+\mathrm{O}_{2}+4 \mathrm{H}_{2} \mathrm{O} \rightarrow 2 \mathrm{Fe}(\mathrm{OH})_{3}+2 \mathrm{H}^{+}[86,87]$. In neutral anoxic environments, it has become clear that anoxygenic photosynthetic bacteria and nitrate-reducing bacteria are the two major functional groups to oxidize iron [86,87]. The anoxygenic photosynthetic bacteria (photoferrotrophy) are phylogenetically diverse, including the purple sulfur 


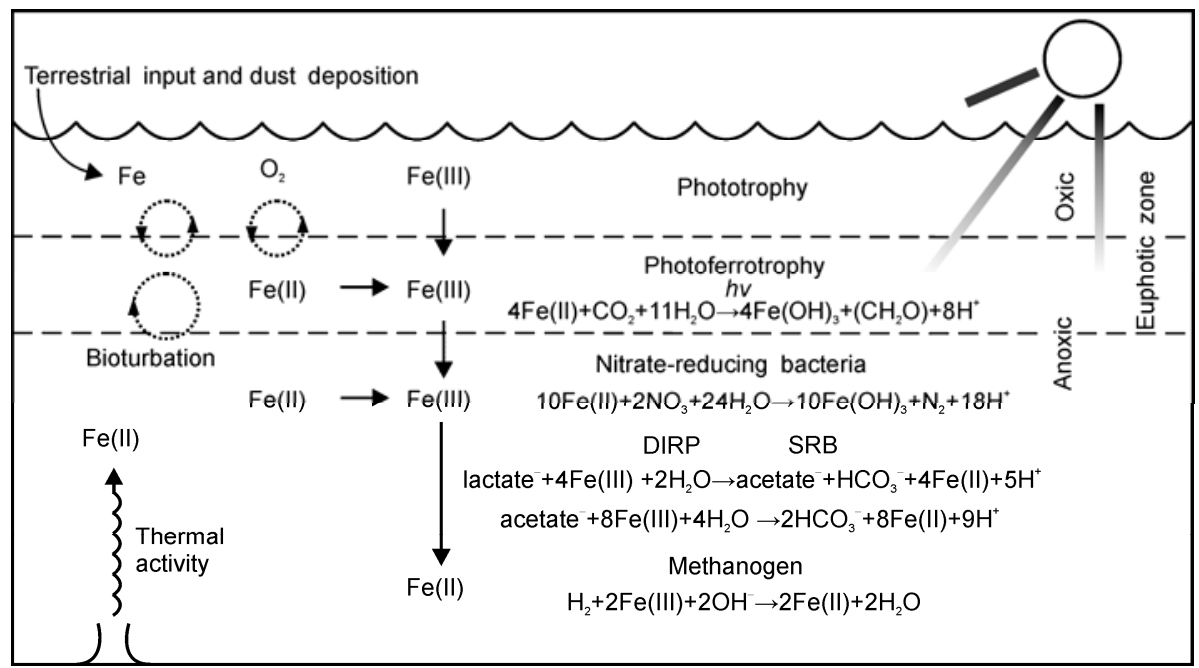

Figure 3 Iron cycle and related GFGs.

bacterium Thiodictyon sp. from $\gamma$-proteobacteria, purple non-sulfur bacterium Rhodobacter ferrooxidans in $\alpha$-proteobacteria, and green sulfur bacterium Chlorobium ferrooxidans in $\delta$-proteobacteria [86-89]. However, all photoferrotrophy shows a similar pathway involved in $\mathrm{Fe}(\mathrm{II})$ oxidation, which is linked to respiratory systems coupled with $\mathrm{CO}_{2}$ fixation [86-89]. More evidence has emphasized the importance of nitrate-dependent iron-oxidizing bacteria (e.g. Ferroglpbus placidus) in anoxic Fe(II) oxidation around circumneutral $\mathrm{pH}$, which are capable of reducing nitrate to nitrogen gas using $\mathrm{Fe}(\mathrm{II})$ as an electron donor [86]. This process can be of enzymatic catalysis or indirect chemical reactions in which the intermediate nitrite generated from nitrate reduction can chemically oxidize $\mathrm{Fe}(\mathrm{II})$ (4Fe(II) + $2 \mathrm{NO}_{2}^{-}+6 \mathrm{H}^{+} \rightarrow 4 \mathrm{Fe}(\mathrm{III})+\mathrm{N}_{2} \mathrm{O}+3 \mathrm{H}_{2} \mathrm{O}$ ) [90]. During $\mathrm{Fe}(\mathrm{II})$ oxidation, various $\mathrm{Fe}(\mathrm{III})$-minerals, including hydrous ferric oxide, goethite and lepidocrocite, formed at the cost of soluble or solid-phase $\mathrm{Fe}(\mathrm{II})$ (siderite, vivianite, magnetite, iron sulfide) $[86,88,90]$.

Since the isolation of dissimilatory $\mathrm{Fe}(\mathrm{III})$-reducing prokaryotes (DIRP) more than 20 years ago (e.g. Geobacter metallireducens [91]; Shewanella oneidensis [92]), microbial $\mathrm{Fe}(\mathrm{III})$ reduction has received considerable attention. In DIRP, electrons are generated after the oxidation of hydrogen gas or low-molecular organic matter, and then are transferred from cellular membranes to $\mathrm{Fe}(\mathrm{III})$-minerals outside the cell [93]. Understanding of the Fe(III) reduction by DIRP has been improved greatly with regard to the types of microorganisms, metabolic processes and electron transferring mechanisms [93]. In addition to the well-known DIRP, a wide variety of anaerobes also are considered to conduct $\mathrm{Fe}$ (III) reduction in natural settings (e.g. some fermentative microorganisms [94], sulfate-reducing bacteria $[95,96]$, and some methanogens $[97,98])$. In contrast to soluble electron acceptors (e.g. nitrate and sulfate) present in anoxic environments, Fe(III) occurs as solid phases (oxides or silicate), leaving dissimilatory $\mathrm{Fe}(\mathrm{III})$ reduction as the preferred pathway. Various minerals (e.g. magnetite, vivianite, siderite) can be formed during this process, depending on the initial minerals and geochemical conditions. It has been proposed that microbial Fe(III) reduction may be one of the earliest respiration pathways in Earth history [99].

In comparison with nearly neutral environments, ironcycling GFGs are quite different in acidic conditions (i.e. acid mine drainages). In acidic environments, Thiobacillus and Leptospirillum have been found to predominate during aerobic Fe(II) oxidation [100], whereas Acidobacterium shows a predominance in the anaerobic reduction of $\mathrm{Fe}(\mathrm{III})$ minerals [101].

\section{Identification diagnostics of GFGs in sediments and rocks}

\subsection{Photosynthetic GFGs}

As stated earlier, photosynthetic GFGs preserved in rocks are hard to identify by morphological examination. The commonly used geochemical and mineralogical records can indicate redox potential of the water column, and thus provide indirect inference for the presence of photosynthetic GFGs. In the past several decades, a variety of biomarkers have been found to be specific for modern photosynthetic GFGs, which can be extrapolated to ancient times. Cyanobacteria can be inferred by the presence of 2-methylhopanoids, including 2-methylhopanepolyols and 2-methylhopanes, especially those with a carbon number $>31$ [102]. Some cyanobacteria also can biosynthesize specific branched alkanes, such as 7-methylheptacosane and 8-methylheptacosane [103]. Green sulfur bacteria also have some specific biomarkers, such as maleimides (1H-pyrrole-2,5diones) [104], 2-alkyl-1,3,4-trimethylbenzene and C40 isorenieratene [105]. The biomarkers specific for diatoms include $\mathrm{C}_{25}$ and $\mathrm{C}_{30}$ highly branched isoprenoids (HBI) [106] and 24-nor-cholesterols [107]. Dinoflagellates can biosyn- 
thesize dinosterol (4 $\alpha, 23,24$-trimethyl-5 $\alpha$-cholan-22-en-3 $\beta$ ol), while coccolithes are the dominant precursors of long chain alkenones [108]. However, caution should be taken when using biomarkers to interpret origins. For example, 2-methylhopanoids also have been detected in bacteria other than cyanobacteria. Thus, multiple lines of evidence are needed for the robust confirmation of specific GFGs.

\subsection{GFGs in methane cycling}

Microbes involved in $\mathrm{CH}_{4}$ cycling usually have diagnostic lipid compounds and/or depleted carbon isotopic composition, which can be used as indicators of the related GFGs in ancient times. In cold seeps of modern seas, methanotrophic archaea encompass the following three clades: ANME-1, ANME-2 and ANME-3 [109]. ANME-1 lipids are featured by GDGTs dominated by $0-3$ cyclopentane rings, while ANME-2 biosynthesizes mainly sn2-hydroxyarchaeol and crocetane (2,6,11,15-tetremethylhexadecane). ANME-3 is characterized by $s n 2$-hydroxyarchaeol and PMI $(2,6,10,15$, 19-pentamethylicosane) [110]. In contrast, aerobic methanotropic bacteria of Group I synthesize 3-methylhopanoids [111] and $\mathrm{C}_{16}$ mono-saturated fatty acids, while those of Group II synthesize $\mathrm{C}_{18}$ mono-saturated fatty acids.

Furthermore, lipids derived from methanotrophs normally show a highly depleted carbon isotope composition, which is inherited from ${ }^{13} \mathrm{C}$-depleted biogenic $\mathrm{CH}_{4}$. Methane produced via the acetate pathway has a $\delta^{13} \mathrm{C}$ range from $-50 \%$ o to $-65 \%$ o, and the $\mathrm{CO}_{2} / \mathrm{H}_{2}$ pathway will result in $\mathrm{CH}_{4}$ with more depleted $\delta^{13} \mathrm{C}$ values $(-60 \%$ o to $-110 \%$ ) [112]. Integration of diagnostic biomarkers with ${ }^{13} \mathrm{C}$-depleted isotope records will allow a robust confirmation of $\mathrm{CH}_{4}$-cycling GFGs present in Earth history.

In addition to lipid biomarkers and carbon isotopes, some specific minerals also can provide a clue for the activity of $\mathrm{CH}_{4}$-cycling GFGs. In cold seeps of the modern sea floor, great abundances of chemoautotrophic microorganisms have been found. $\mathrm{HCO}_{3}^{-}$, produced by anaerobic $\mathrm{CH}_{4}$ oxidation, is oversaturated in seawater, and interacts with $\mathrm{Ca}^{2+}$ to precipitate calcium carbonate. These minerals, known as cold seep carbonates, often contain thrombolite with aragonite cements of radial and concentric structures, or brecciated carbonates from overpressured gas movements. Associated with these carbonate minerals are barite and gypsum, forming encrustations, mound and slabs of various sizes, with thicknesses of meters to tens of meters [113]. Presence of over-saturated $\mathrm{HS}^{-}$facilitates the deposition of framboidal pyrite. The authigenic carbonates formed in cold seeps normally show a depletion of ${ }^{13} \mathrm{C}$, while barite has a relative ${ }^{34} \mathrm{~S}$ enrichment. Some of the sedimentary structures and isotope compositions can help to identify events related to gas hydrate release and their impact on the Earth environments and ecosystems $[114,115]$. In contrast with cold seeps, hydrothermal vents are mainly composed of sulfide, such as pyrite, chalcopyrite, pyrrhotine and blende. Massive sulfide ores containing microfossils are commonly regarded as remains of ancient black smoker systems [116].

\subsection{GFGs in sulfur cycling}

Precise identification of the GFGs related to sulfur metabolism is the key to unravel the sulfur cycle and oceanic geochemistry throughout Earth history. Current diagnostics include biomarkers, iron geochemistry and sulfur isotope compositions. Green sulfur bacteria (Chlorobiaceae) and purple sulfur bacteria (Chromatiaceae) are two important anaerobic microbes which utilize $\mathrm{H}_{2} \mathrm{~S}$, and are good indications for euxinic oceans, if found in ancient deposits. They both have particular biomarkers. Chlorobactane, isorenieratane and trimethyl aryl isoprenoids are the main biomarkers of green sulfur bacteria, while okenane is diagnostic of purple sulfur bacteria [54]. As the carbon fixation pathway in green sulfur bacteria is the Krebs cycle featured by only small isotope fractionation, the organic compounds biosynthesized by these bacteria show a ${ }^{13} \mathrm{C}$-enriched isotopic composition. The carbon isotopic composition of trimethyl aryl isoprenoids and other potential compounds, such as farnesane, also can be diagnostic of green sulfur bacteria. Sulfate-reducing microbes identified in modern environments show some biomarkers, such as short-chained $\left(\mathrm{C}_{15}\right.$, $\mathrm{C}_{17}$ ) iso- and anteiso-fatty acids [117]. Unfortunately, these fatty acids are transformed very easily during early diagenesis to other more geologically stable compounds, but of less specific biotic diagnostic value (i.e. iso- and anteisoalkanes). Other potential biomarkers of ancient sulfatereducing bacteria are yet to be explored.

It is known that $\mathrm{H}_{2} \mathrm{~S}$ is an important by-product of microbial sulfate reduction, and can react with iron (II) to form pyrite that is ultimately preserved in ancient deposits. It is interesting to note that pyrite grains show a size variation related to their sedimentary environmental conditions. In extremely anoxic or euxinic environments, microbial sulfate reduction occurs in the water column where the iron concentration is very low. In this case, the pyrite grains formed are framboidal with a small but homogeneous size range (mean value of 4-5 $\mu \mathrm{m}$ ) [118]. The size distribution pattern of framboidal pyrite grains and the iron geochemical features are useful tools to explore sulfidic oceans and associated GFGs in ancient times [119].

Sulfur isotopic composition of pyrite could be an effective record for the sulfur cycle and the related GFGs [42]. A large kinetic fractionation of sulfur isotopes exists during microbial sulfate reduction, resulting in ${ }^{32} \mathrm{~S}$-depleted pyrite. When the oceanic sulfate concentration is very low, pyrite formed tends to yield very high $\delta^{34} \mathrm{~S}$ values, such as those found in Precambrian rocks [120]. The sulfur isotopic composition of pyrite also can be used to locate the redox boundary in ancient oceans. When the redox boundary is located below the sediment-water interface, pyrite $\delta^{34} \mathrm{~S}$ is featured by high values with a very large variation range. 
Both ${ }^{33} \mathrm{~S}$ and ${ }^{36} \mathrm{~S}$ of low contents can be measured precisely by advanced techniques. This refinement in techniques makes it possible to discriminate microbial sulfate reduction from sulfur disproportionation in ancient times because of their distinct ${ }^{33} \mathrm{~S}$ fractionation coefficient $\left({ }^{33} \lambda\right)[47,121,122]$.

\subsection{GFGs in nitrogen cycling}

The identification of nitrogen-metabolizing GFGs in sediments and rocks is the key to decipher the nitrogen cycle in geological history, and can only rely on microbial membrane lipids and nitrogen isotopic signatures. Some diazotropic cyanobacteria (e.g. Anabaena cylindrical) can biosynthesize specific biomarkers (e.g. glycolipids in heterocysts), which can protect the $\mathrm{O}_{2}$-sensitive nitrogenase from inactivation. The heterocyst glycolipids can be preserved in sediments for a long time because of their resistance to degradation, and can be used as biomarkers to trace nitrogen-fixation cyanobacteria in ancient oceans [78]. Specific unsaturated bacteriohopanepolyols with four hydroxyl side chains are diagnostic of nitrogen-fixing cyanobacteria, Trichodesmium, the dominant microbes in modern oceans [123].

Ammonia-oxidizing crenarchaeota possess a unique biomarker (i.e. crenarchaeol with cyclopentyl rings), which has been preserved even in Cretaceous marine strata [124,125]. The number of cyclopentyl rings in the lipids of marine ammonia-oxidizing crenarchaeota shows a strong positive correlation with sea surface temperatures (SST). Based on this observation, a paleothermometer $\left(\mathrm{TEX}_{86}\right)$ was established and widely applied to ancient SST reconstruction [126]. The biomarkers of anammox bacteria (ladderanes) are the membrane lipids of anammoxosome, a compartment that prevents the poisonous hydrazine from entering the cell [127]. Ladderanes have been used to trace the anammox process in the Arabian Sea over the last glaciation [128], which is currently the only known way to identify the presence of anammox in geological history.

In addition to these diagnostic lipids preserved in sediments, nitrogen isotopes $\left(\delta^{15} \mathrm{~N}\right)$ also can reflect the presence of nitrogen-related GFGs. Cyanobacteria can induce fractionation of nitrogen isotopes with organic $\delta^{15} \mathrm{~N}$ values ranging from $-3 \%$ o to $1 \%$. Nitrogen isotopic fractionation during nitrogen-fixation and non nitrogen-fixation has been discriminated clearly in supratidal and intertidal microbial mats. Organic nitrogen isotope composition was clearly more negative in supratidal than in intertidal microbial mats, and heterocyst glycolipids, the biomarkers of some nitrogen-fixing cyanobacteria, were identified only in supratidal microbial mats [78]. The negative shifts of $\delta^{15} \mathrm{~N}$ during Cretaceous oceanic anoxic events and across the PermianTriassic boundary both indicate past blooms of cyanobacteria $[129,130]$, consistent with the occurrence of enhanced cyanobacterial biomarkers [131]. Nitrogen fixation needs more energy than nitrate-assimilating metabolism, and mi- croorganisms, even cyanobacteria, prefer nitrate uptake to nitrogen-fixation. Thus, at some critical periods in geologic history, enhanced nitrogen fixation, shown by $\delta^{15} \mathrm{~N}$ due to marine cyanobacteria blooms, may indirectly indicate low nitrate concentrations and anoxic conditions in ancient sea water.

Denitrification, including anammox, can cause a great fractionation of nitrogen isotopes. The ${ }^{15} \mathrm{~N}$-enriched nitrate left after denitrification can be assimilated by primary producers, such as algae, to biosynthesize organic matter with relatively positive $\delta^{15} \mathrm{~N}$, averaging between $7 \%$ and $9 \%$ [132]. Elevated $\delta^{15} \mathrm{~N}$ values may indicate the presence of relatively strong denitrification, and vice versa. For example, relatively higher $\delta^{15} \mathrm{~N}$ values and higher $\mathrm{N}_{2} \mathrm{O}$ concentrations observed in interglacial ice cores, reveal stronger denitrification in interglacial compared to glacial periods. The nitrogen loss may become more severe because of the much stronger denitrification during interglacial periods, and further cause the decline of marine primary productivity [60]. However, pure culture experiments of some diazotrophic cyanobacteria have revealed that $\delta^{15} \mathrm{~N}$ records cannot discriminate nitrogen-fixation from non nitrogen-fixation [78], with both nitrate uptake and nitrogen fixation showing negative $\delta^{15} \mathrm{~N}$ values. In addition, the $\delta^{15} \mathrm{~N}$ values also may be affected by microbial degradation of organic matter, terrestrial organic input and diagenesis. Thus, caution should be taken when interpreting the nitrogen cycle on the basis of $\delta^{15} \mathrm{~N}$ records throughout geologic history.

\subsection{GFGs involved in iron redox cycle}

GFGs related to the iron redox cycle are hard to preserve in rocks and, if preserved, they are difficult to classify into a specific group. It was widely assumed that both the branched (i.e. 10 -methyl $\left.\mathrm{C}_{16: 0}\right)$ and iso- $\left(i \mathrm{C}_{17: 1 \omega 7 \mathrm{c}}\right)$ fatty acids could be used as indicators of DIRP. However, these fatty acids also are biosynthesized by sulfate-reducing bacteria [133]. To date, a series of diagnostics of these GFGs are proposed, including mineral types and assemblages, and iron isotope compositions.

Magnetite is one of the typical products formed during microbial Fe(III) reduction. Biogenic and inorganic magnetite cannot be differentiated by morphological features [134], but rather by other properties. In an experimental study on Shewanella oneidensis, Perez-Gonzalez et al. [135] found that cell fragments and metabolic materials can co-precipitate with magnetite. On the basis of analysis of precipitated magnetite by thermogravimetry and FT-IR, the authors revealed that organic matter enclosed in biogenic magnetite can be of diagnostic use to differentiate inorganic magnetite. In contrast to chemically-synthesized magnetite, biogenic analogs are characterized as poor crystallinity $[135,136]$ and excess $\mathrm{Fe}^{2+}$ content, with an $\mathrm{Fe}^{2+} / \mathrm{Fe}_{\text {total }}$ ratio of $0.4-0.6$ [136-138] which, in turn, results in the presence of distinct lattice parameters [136] and the shifting of vibrating adsor- 
bent peaks in Raman spectra toward higher frequency [135].

In addition to oxides and hydroxides, clay minerals are another important reservoir of structural Fe(III), which can be used as an electron acceptor by $\mathrm{Fe}(\mathrm{III})$-reducing microorganisms [139]. Upon microbial reduction, $\mathrm{Si}, \mathrm{Al}$ and other elements in clay minerals can be released into aquatic systems, favoring the precipitation of silica, $\mathrm{Fe}(\mathrm{II})$-minerals (sulfides), calcite and other secondary minerals [96,139]. The silica and iron sulfide formed could be transformed to more stable phases (quartz and pyrite, respectively). Consequently, the mineral assemblages (e.g. aggregates of quartz and pyrite, calcite intergrown with phyllosilicate) and other geochemical records (e.g. sulfur isotope composition) help to identify the presence of Fe(III)-reducing microorganisms [140,141].

It is notable that, in the past decade, iron isotope composition has had a rapid application in the detection of microbial activities. The growing evidence suggests that hydrous ferric oxide induced by photoferrotrophy indicates $\delta^{56} \mathrm{Fe}$ values greater than aqueous $\mathrm{Fe}^{2+}$ values (by ca. $1.5 \%$ ), which is caused by both equilibrium fractionation (ca. 2.9\%o) between $\mathrm{Fe}^{3+}$ and $\mathrm{Fe}^{2+}$ in aquatic system, and kinetic fractionation during the co-precipitation of oxides and $\mathrm{Fe}$ (III)aq $(\sim-1.4 \%$ o $)[142,143]$. In contrast, the iron oxides produced by nitrate-dependent iron-reducing bacteria show a $\delta^{56} \mathrm{Fe}$ value $3 \%$ greater than aquatic $\mathrm{Fe}^{2+}$, but close to the equilibrium fractionation between $\mathrm{Fe}^{3+}$ and $\mathrm{Fe}^{2+}$ in aquatic systems at room temperature [144]. An experimental study by Crosby et al. [145] indicated that soluble $\mathrm{Fe}^{2+}$ produced by the DIRP, Geobacter sulfurreducens, shows $\delta^{56} \mathrm{Fe}$ values $3 \%$ more depleted than reactive $\mathrm{Fe}$ (III) on iron oxide surfaces, which was caused by fractionation during atomic and electron exchanges between them.

\section{GFGs roles over major environmental changes}

Photosynthetic GFGs are some of the most important microbes in the evolution of the Earth's environments. These GFGs enable the biosynthesis of organics using $\mathrm{CO}_{2}$ and sunlight energy. Thus, they exert an important effect on the Earth system via regulation of the carbon cycle. In addition, the molecular oxygen released in photosynthesis further changes the Earth's environments via influencing the cycles of carbon, sulfur, nitrogen and iron which, in turn, cause a significant impact on the origin and evolution of other organisms. Photosynthesis is believed to be the dominant dynamic process that triggered the evolution of the Earth from oxygen-free to oxygenic system, which is the prerequisite of the presence of metazoans. Photosynthetic GFGs are, to some extent, the most significant driver to change the Earth's environments. Photosynthesis has been discussed in detail elsewhere [14,146], and will not be discussed further here.

The GFGs involved in the carbon cycle have a great im- pact on marine environments as well as on the atmosphere, and cause the association of abnormal paleoclimate with carbon cycle variation. The roles of these GFGs are archived in rocks in the form of organics and inorganics, such as minerals. The GFGs metabolizing sulfur species also can influence the atmosphere via release of sulfur-containing organics which are quickly transformed into dimethyl sulfide in the air, among other mechanisms. While it is difficult to identify and confirm such processes in ancient times, we can demonstrate the roles played by these GFGs in changing marine environments by exploring the sulfur isotope composition in rocks. Nitrogen-metabolizing GFGs mainly impact organisms and environments by changing their nutritional status, which may be recorded in the nitrogen isotope composition of organic compounds.

It is notable that a variety of GFGs interacted during environmental change across critical periods in Earth history. For example, nitrogen-fixing microbes (mainly cyanobacteria), sulfur-metabolizing microbes (green sulfur bacteria) and $\mathrm{CH}_{4}$-oxidizing bacteria (Type $\mathrm{I}$ ) all have been documented to have caused blooms during the transitional period from the Permian to Triassic. Associated with these microbial blooms was the presence of a sulfidic ocean, low sulfate concentration in seawater, abnormal paleoclimate, fluctuating carbon cycle, and mass extinction of both marine and terrestrial fauna and flora. The co-occurrence of these events shows interactions not only among GFGs, but also with the paleoenvironments of that interval.

\subsection{GFGs involved in abnormal climate}

Both $\mathrm{CO}_{2}$ and $\mathrm{CH}_{4}$ are the most important greenhouse gases, and also are critical components in the global carbon cycle. As a result, an abnormal carbon cycle usually is associated with abnormal climate change, such as cold and warm periods. In ancient times, enhanced activities of methanogens and methanotrophs have been documented to closely correlate with paleoclimate change. These $\mathrm{CH}_{4}$-related GFGs, independently or in cooperation with other GFGs, played positive roles on paleo-environments. For example, endophytic methanotrophic bacteria have been found to have lived in symbiosis with Sphagnum species in peatlands [147]. This symbiotic phenomenon is believed to have been dominant in the global Sphagnum peatlands. Methanotrophic bacteria, of high diversity [148], oxidize $\mathrm{CH}_{4}$ to $\mathrm{CO}_{2}$, which is then fixed by Sphagnum as the carbon source for photosynthesis. This symbiotic process allows $\mathrm{CH}_{4}$ to cycle within peatland organisms, mitigating $\mathrm{CH}_{4}$ release to the atmosphere. In the northern hemisphere, Sphagnum species cover an area of $1.5 \times 10^{6} \mathrm{~km}^{2}$, and it could be estimated that this symbiosis will reduce the release of $\mathrm{CH}_{4}$ from peatlands to the atmosphere [149]. However, since the last glaciation, the circum-arctic peatlands have been observed to have expanded explosively between 12 and $8 \mathrm{ka}$, in agreement with the sustained peak in concentration of at- 
mospheric $\mathrm{CH}_{4}[150,151]$. This reveals the importance of peatland contribution to atmospheric $\mathrm{CH}_{4}$, although reduced by microbial symbiosis. Massive release of deep-sea $\mathrm{CH}_{4}$ also was found to occur during the warm intervals of the last glaciation [152-154], though remained further confirmation. It appears that peatlands are probably not one of the major contributors to the progressive increase of atmospheric $\mathrm{CH}_{4}$ concentration during the recent $5 \mathrm{ka}[150,155]$. It has been found that, of all the $\mathrm{CO}_{2}$ fixed by Sphagnum species, the relative $\mathrm{CO}_{2}$ proportion derived from methanotrophic oxidation is related to peatland hydrological conditions $[147,156]$. Consequently, precipitation impacts the symbiosis of methanotrophs with Sphagnum species, and the release of peatland $\mathrm{CH}_{4}$. We should pay particular attention to this with regard to the current situation of increasing global warming [157].

In Earth history, some warm periods that occurred immediately after major glaciations have been found to be associated with massive releases of $\mathrm{CH}_{4}$ from sea floor gas hydrates. One typical example is the Doushantuo warm period after the Nantuo glaciation in Neoproterozoic. Cap carbonates from several sections show extremely ${ }^{13} \mathrm{C}$ depleted carbon isotopic values (as low as $-48 \%$ o), previously suggesting a widespread $\mathrm{CH}_{4}$ release in this warm period in south China [115]. However, this explanation awaits further investigation because different interpretation was recently proposed for the ${ }^{13} \mathrm{C}$ depleted cap carbonate [158]. The Paleocene-Eocene thermal maximum (55 Ma) is a welldocumented thermal interval. Atmospheric temperature is believed to have increased by $5-9^{\circ} \mathrm{C}$ within a very short period (several thousand years) $[159,160]$. The greenhouse effect from oxidation of $\mathrm{CH}_{4}$ released from a tremendous volume of gas hydrate has been proposed widely to have triggered this warm event $[161,162]$, although this hypothesis is rejected by other researchers [163]. Pancost et al. [164] identified the bloom of methanotrophic bacteria in wetlands cross the Paleocene-Eocene boundary, indicated by the occurrence of ${ }^{13} \mathrm{C}$-depleted hopanes. These studies revealed a potential causal connection among $\mathrm{CH}_{4}$-related GFGs, gas hydrate release and the thermal climate, in which GFGs might show positive or negative feedback to climate change by regulating the $\mathrm{CH}_{4}$ cycle. Association of warm climate with elevated atmospheric $\mathrm{CO}_{2}$ concentration also was commonly present in the Mesozoic, such as in the interval across Triassic-Jurassic boundary, early Toarcian in the Jurassic and early Aptian in the Cretaceous. However, it remains unclear how GFGs show a response to the events observed in these warm intervals.

Abnormal carbon cycles shown by carbon isotope excursions also are associated with biotic mass extinctions (e.g. end Permian and end Cretaceous), in addition to the associated major climate change [165,166]. Stanley [167] proposed that the dominant cause for carbon isotope excursions was associated with the Phanerozoic mass extinctions is change in the respiration rate of marine bacteria. The tem- perature variations occurring during these biotic crises would likely have strongly affected microbial respiration rate which, in turn, influences the amount of ${ }^{13} \mathrm{C}$-depleted organic matter buried and the $\delta^{13} \mathrm{C}$ value of the marine inorganic carbon pool. This infers a linkage among microbes, abnormal carbon cycle, climate change and biotic crisis, which awaits further investigation. Luo et al. [168] discovered that blooms of cyanobacteria or green sulfur bacteria show a strong link with carbon isotope excursion across the Permian-Triassic boundary at the Meishan section. They stated that GFGs variations immediately following the faunal mass extinction could have strongly affected carbon isotope fractionation.

\subsection{GFGs in sulfidic oceans}

It is well known that anoxic seawater environments mainly develop through the $\mathrm{O}_{2}$ consumed in the water column by abundant organics derived from blooming microbes. The euxinic ocean is characterized by an anoxic condition enriched in $\mathrm{H}_{2} \mathrm{~S}$. A well-known ancient euxinic ocean was that of the Late Palaeoproterozoic to Late Neoproterozoic or the so called Canfield Ocean, proposed by Canfield [169], which lasted for more than $1 \mathrm{Ga}$. Elevated atmospheric $\mathrm{O}_{2}$ content of early Earth promoted continental erosion and thus allowed an increase in oceanic sulfate content. Microbial reduction of elevated sulfate led to hydrogen sulfide surpassing $\mathrm{Fe}$ (II) volume, and $\mathrm{H}_{2} \mathrm{~S}$ began to accumulate in the ocean. As a result, the ferruginous ocean was replaced by the euxinic ocean, occurring about $1.84 \mathrm{Ga}$ ago [170]. In the Phanerozoic, euxinic oceans also occurred frequently, and interrupted the normal oxic oceanic sedimentation. The main intervals known with euxinic conditions in the Phanerozoic are Late Cambrian [171], the transition from Ordovician to Silurian [172], Late Devonian [173], late Permian to early Triassic $[55,174]$ and several intervals in the Cretaceous known as the Anoxic Ocean Events [175]. It remains unclear whether these euxinic oceans were global, or caused by local restricted sedimentary basin conditions (e.g. as in the Black Sea).

The typical GFGs in euxinic oceans are characterized by microbes capable of reducing sulfate, and oxidizing $\mathrm{H}_{2} \mathrm{~S}$ in anaerobic and aerobic pathways. Sulfate-reducing bacteria or archaea are the main microbes that carry out sulfate reduction. This metabolism produces a great amount of $\mathrm{H}_{2} \mathrm{~S}$ to cause euxinic oceans, leaving the sulfate residue enriched in heavy sulfur isotopes [54,176]. Anaerobic $\mathrm{H}_{2} \mathrm{~S}$-oxidizing microbes mainly include green sulfur bacteria and purple sulfur bacteria. The two microbes, requiring both sunlight and $\mathrm{H}_{2} \mathrm{~S}$ in a sulfidic photic zone, oxidize $\mathrm{H}_{2} \mathrm{~S}$ to sulfate [54,55]. Aerobic $\mathrm{H}_{2} \mathrm{~S}$-oxidizing bacteria may reside in the same horizon, or much shallower than, anaerobic $\mathrm{H}_{2} \mathrm{~S}$ oxidizing bacteria [57], and they mainly produce elemental sulfur [177].

In euxinic oceans, some GFGs are capable of denitrifica- 
tion, anaerobic ammonia oxidation and nitrogen-fixation [178]. These GFGs convert most of the biologically available nitrogen $\left(\mathrm{NH}_{3}, \mathrm{NH}_{4}^{+}, \mathrm{NO}_{3}^{-}, \mathrm{NO}_{2}^{-}\right)$to inert nitrogen gas in euxinic conditions. This means that euxinic oceans would be deficient in bioavailable nitrogen and would promote microbial nitrogen fixation dominantly driven by cyanobacteria $[178,179]$. Some archaea with unknown functions also could play important roles in development of euxinic oceans [180,181].

\subsection{GFGs in seawater with low sulfate concentration}

Sulfate concentration is very high (about $29 \mathrm{mmol} / \mathrm{L}$ ) in modern oceans. However, oceanic sulfate concentration in geological history varied frequently, and was characterized by several intervals with extremely low values. The Precambrian ocean, for example, had very low sulfate concentrations [44,182]. In the Phanerozoic, the oceans also were characterized by the alternation of high and low sulfate concentrations [183,184], with low values being reported from the Late Cambrian to Early Devonian, PermianTriassic transition and Triassic-Jurassic transitional period [176,185].

Methanogens are the main GFGs in the oceans with low sulfate concentration. Methanogens will compete with sulfate-reducing bacteria for $\mathrm{H}_{2}$ and acetate [186]. Decline in oceanic sulfate concentration facilitates methanogen bloom by obtaining much more $\mathrm{H}_{2}$ and acetate [54]. In addition, because more than $50 \%$ of organics are mineralized through sulfate reduction [187], low sulfate concentrations allow more organics to remain unmineralized and present in the methanogenesis zone, which in turn causes the methanogen blooms.

Methanotrophs, particularly aerobic methanotrophs, also are dominant GFGs in oceans with low sulfate content. The enhanced metabolism of methanogens illustrated above promotes the production of $\mathrm{CH}_{4}$. It is well known that most (80\%) methane [188] is oxidized by the consortium of anaerobic methanotrophs and sulfate-reducing bacteria using sulfate as an important elector acceptor [35]. Low oceanic sulfate content and high production of $\mathrm{CH}_{4}$ clearly promotes the metabolism of aerobic methanotrophs, including type I, II and X. Type I methanotrophs, indicated by definite biomarkers such as 3-methylhopanepolyols, are abundant in modern lacustrine environments with low sulfate content, but scarce in modern oceanic environments [123]. Type I methanotrophs also were found to be abundant in Precambrian strata, in particular in the late Archean when oceanic sulfate concentration is believed to have been low [54,189]. Recently, extremely low oceanic sulfate concentrations [176] also were found in association with high abundance of type I methanotrophs [174] in strata straddling the PermianTriassic transition. Consequently, typical GFGs in environments with low sulfate content are methanogens and aerobic methanotrophs, along with some others, such as photosyn- thetic GFGs.

As discussed above, oceanic sulfate in low contents could exert important impacts on the Earth's environments and biogeochemical cycles. Enhanced methanogenesis and declining anaerobic oxidation of methane allow an elevated flux of methane to the surface ocean and to the atmosphere. Enhanced release of methane, a strong greenhouse gas, tends to increase atmospheric temperature and continental erosion, causing enhanced input of nutrients and sulfate into the ocean, affecting other biogeochemical cycles. Quantification or semi-quantification of these fluxes is needed to decipher these changes in the Earth's system.

Although oceanic sulfate plays an important role on microbial geochemical cycles, its concentration remains largely unknown in ancient times, in particular with controversial data reported for the Precambrian. It was recently found that $\mathrm{H}_{2} \mathrm{~S}$ was present only in a very small portion of the shallow waters on the continental margin, with most being dominated by $\mathrm{Fe}$ (II) in the end-Palaeoproterozoic and end-Neoproterozoic oceans [190,191], indicative of low sulfate concentration. This situation could well have continued into the Late Cambrian [192]. However, little is known about the evolution of this pattern and the causes of low concentrations of oceanic sulfate during the two intervals.

\subsection{GFGs related to nutritional status}

Nitrogen, phosphorous and iron are important nutrients that control growth in organisms. In shallow marine environments, these nutrients can be input from the continents to the oceans via surface runoff and wind dust. Across the Paleocence-Eocence and Permian-Triassic boundaries, enhanced terrestrial weathering contributed more $\mathrm{N}, \mathrm{P}$ and $\mathrm{Fe}$ to marine environments. The marine photosynthetic GFGs and diazotrophic GFGs flourished, and led to negative shifts of $\delta^{15} \mathrm{~N}[130,131,174]$. In most cases, the GFGs cannot only passively respond to nutrient change, but they also positively impact marine environments. For example, the degradation of dead primary producers in eutrophic oceans may consume most free oxygen in the water column, and result in anoxic conditions. Accordingly, green sulfur and purple sulfur bacteria may flourish in photic zones [174], and enhanced denitrification may emit the greenhouse gas $\mathrm{N}_{2} \mathrm{O}$ into the atmosphere [193]. Accumulation of organic matter and anoxic conditions may favor flourishing of methanogens, and enhance the methane emissions [194]. Thus, nutrient exchange in the water column can trigger a series of biogeochemical processes among different GFGs, which significantly affect marine environments. The presence of a variety of GFGs and the associated marine environmental changes across the Permo-Triassic boundary represented such a case in Earth history [130,131,165,174].

In the pelagic oligotrophic regions, nitrate is limited and the bioavailable nitrogen species can only be provided 
through cyanobacterial nitrogen-fixation. The nitrogen species fixed may then directly control marine primary productivity [195]. In oligotrophic conditions, the nitrogen cycle driven by nitrogen-related GFGs may be the key factor to determine marine nutrient conditions. It is estimated that nitrogen fixed is $(0.06-25) \times 10^{12}$ mol per year in modern marine environments [196]. This nitrogen pool becomes indispensable in supporting the vast marine food chains. However, nitrogen-fixation rates can be restricted by $\mathrm{Fe}$, Mo and P inputs by wind dust $[63,197,198]$. During glacial periods featured by relatively strong wind dust, increased inputs of iron could potentially have enhanced cyanobacterial nitrogen-fixation and promoted marine primary productivity in pelagic regions [199].

It should be noted that an acidified ocean induced by elevated atmospheric $\mathrm{PcO}_{2}$ may reduce ammonia-oxidation rates of $\mathrm{AOA}$ and $\mathrm{AOB}$, but promote cyanobacterial nitrogen-fixation [200]. For example, across the PermianTriassic boundary, volcanic eruptions contributed more $\mathrm{CO}_{2}$ to the atmosphere, which may have favored diazotrophic cyanobacteria to compete over phytoplankton in low nitrate environments [201]. Ocean acidification also may prevent diatoms and coccolithes from acquiring more soluble iron, which further makes iron more restricted for marine primary producers [202]. Thus, during geological periods with elevated atmospheric $\mathrm{PCO}_{2}$, diazotrophic cyanobacteria would be the dominant primary producers and may play an important role in the marine ecological systems.

An excess of nutrient elements (e.g. $\mathrm{N}$ and $\mathrm{P}$ ) can favor blooms of some GFGs which, in turn, lead to formation of black shales occurring widely in the geologic history. The black shales are of economic significance since they host a variety of ores, oils and gases, and also can provide insight into the nutrient conditions and seawater chemistry in ancient times [129,132,203]. For example, the lower Cambrian black shales widely distributed on the Yangtze Platform in south China are characterized by the occurrence of geomicrobes and enrichment of polymetallic elements, including Mo and Ni. Enhanced upwelling of nutrient elements (e.g. $\mathrm{N}$ and $\mathrm{P}$ ) at that time may have facilitated the flourishing of cyanobacteria-dominated photosynthetic microbial groups, which contributed abundant organics to the black shales. Sulfate-reducing bacteria may have released hydrogen sulfide in the euxinic waters and resulted in the precipitation and enrichment of metal sulfides [204]. Thus, photosynthetic GFGs and sulfur-metabolizing GFGs may have played key roles in the formation of black shales and associated ores and oil resources throughout Earth history.

\subsection{GFGs involved in the deposition of Precambrian banded iron formation}

Microbes play important roles in facilitating surface energy flow, as well as affecting various geological processes and associated environmental changes via involvement in the iron redox cycle. Through these processes, they impact the carbon cycle, the migration of life elements, and the transportation and transformation of metals and nuclides [86,93]. Here, their contribution to the deposition of Precambrian banded iron formations (BIFs) is specifically reviewed.

BIFs are unique marine sedimentary rocks featured by rhythmic layers of chert and iron-rich minerals (e.g. magnetite, hematite), deposited from 3.6 to $1.8 \mathrm{Ga}$ with a maximum deposition at $2.5 \mathrm{Ga}$ [205]. It is believed that the ocean water during this period was characterized by extremely low sulfate concentration and enriched ferrous iron [206]. To date, the mechanism driving ferrous iron oxidation to form ferric iron in BIFs is still highly debated. $\mathrm{Fe}^{2+}$ oxidation in the ocean was suggested to have been caused by free oxygen generated by cyanobacterial photosynthesis. However, the chemical oxidation of $\mathrm{Fe}^{2+}$ by free oxygen appears to be limited. This is particularly true when we consider the low atmospheric partial pressure of oxygen, which was $10^{-5}$ to $10^{-3}$ times less than present values before the first Great Oxidation (2.45 Ga) [207], allowing localized "oxygen oases" in coastal settings [87], and was still 0.02 to 0.04 times the present atmosphere even in the age of 2.45-1.8 Ga [207], with oxic surface water but anoxic bottom water. BIFs were thus formed in anoxic waters, and this excludes the dominant contribution of cyanobacteria [208]. $\mathrm{Fe}^{2+}$ could be photo-oxidized by ultraviolet photons, but modern laboratory simulations exclude this as a dominant contribution [209]. It is further proposed that photoferrotrophy could accelerate, and thus dominantly contribute to, ferrous iron oxidation in $\mathrm{O}_{2}$-free conditions [19,208,209]. It is notable that the presence of photoferrotrophy in slightly oxic shallow water in ca. $1.9 \mathrm{Ga}$ was confirmed by a negative $\mathrm{Ce}$ anomaly and positive $\delta^{56} \mathrm{Fe}$ values found in Gunflint and iron-stromatolites in Biwabik BIFs in North America [210].

It is believed that heterotrophic microbes were ubiquitous in the BIFs [87] because of the precipitation of a huge amount of $\mathrm{Fe}(\mathrm{III})$, the presence of anoxic bottom water and the organics biosynthesized by photosynthetic plankton (e.g. anoxygenic photosynthetic $\mathrm{Fe}(\mathrm{II})$-oxidizing bacteria). In fact, the negative $\delta^{56} \mathrm{Fe}$ values found in 2.5 -Ga BIFs in Hamersley Basin in Australia and in Transvaal Craton in South Africa support the presence of dissimilatory Fe(III)reducing bacteria [143]. More recently, Li et al. [211] proposed that the GFGs related to iron redox were dominated by photosynthetic plankton and dissimilatory $\mathrm{Fe}$ (III)reducing bacteria on the basis of the co-occurrence of magnetite and apatite, and features observed using Mössbauer spectroscopy and crystal lattice parameters of magnetite.

\section{Conclusions}

Extensive investigation of the GFGs involved in the elemental cycles of carbon, sulfur, nitrogen and iron has been conducted in modern natural environments, allowing a deep 
understanding of the functions of these particular microbes. These GFGs were found to play significant roles in ancient environments, such as the abnormal climates, sulfidic oceans, seawater with low sulfate concentrations, nutritional status of ecosystems, and the deposition of Precambrian banded iron formations. Nevertheless, the significant roles the GFGs have played throughout Earth history are far from being fully deciphered. This situation results from poor preservation and taxonomic challenges in identifying geomicrobes, which show less diversity in morphology and structures in comparison with fauna and flora preserved in rocks. It is notable that geomicrobes are discriminated by diverse functions of ecology, physiology, metabolism and biogeochemistry, making new breakthroughs possible by targeting their functional groups. It is impossible to identify the entire range of geomicrobes, but it is critical to focus on the GFGs, which were preserved in rocks as diagnostic molecular fossils, geochemical fingerprints, and mineral indications. Some advancement in recognizing the diagnostic records has been made in the past, and needs to be continued in the future. The GFGs are proposed here to be the critical geomicrobes in deciphering the interaction between life and environments throughout Earth history.

Two anonymous reviewers are thanked for their constructive comments, and the 30 participants of geobiology of the National Basic Research Program of China are thanked for discussions on geomicrobial functional groups. This work was supported by the National Natural Science Foundation of China (40930210, 40921062 and 41130207), the National Basic Research Program of China (2011CB808800), and the 111 Program (B08030).

1 Morgan J P, Reston T J, Ranero C R. Contemporaneous mass extinctions, continental flood basalts, and 'impact signals': Are mantle plume-induced lithospheric gas explosions the causal link? Earth Planet Sci Lett, 2004, 217: 263-284

2 Love J E. Gaia: A New Look at Life on Earth. Oxford: Oxford University Press, 2000. 1-148

3 Xie S, Gong Y, Tong J, et al. Development from paleontology to geobiology (in Chinese). Chin Sci Bull (Chin Ver), 2006, 51: 2327-2336

4 Yin $\mathrm{H}$, Xie S, Tong J, et al. On the significance of geobiology (in Chinese). Acta Palaeont Sin, 2009, 48: 293-301

5 Xie S, Yin H, Shi X. Geobiology: Interactions and Co-evolution Between Life and Earth Environments (in Chinese). Beijing: Science Press, 2011. 63

6 Kalyuzhnaya M G, Lapidus A, Ivanova N, et al. High-resolution metagenomics targets specific functional types in complex microbial communities. Nat Biotechnol, 2008, 26: 1029-1034

7 Strom S L. Microbial ecology of ocean biogeochemistry: A community perspective. Science, 2008, 320: 1043-1045

8 Falkowski P G, Fenchel T, Delong E F. The microbial engines that drive Earth's biogeochemical cycles. Science, 2008, 320: 1034-1039

9 Des Marais D J. When did photosynthesis emerge on earth? Science, 2000, 289: 1703-1705

10 Gray M W. The endosymbiont hypothesis revisited. Inter Rev Cytol, 1992, 141: 233-357

11 Buick R. The antiquity of oxygenic photosynthesis: Evidence from stromatolites in sulphate-deficient Archaean lakes. Science, 1992, 255: 74-77

12 Buick R. When did oxygenic photosynthesis evolve? Philos Trans R
Soc Lond B, 2008, 363: 2731-2734

13 Olson J M, Blankenship R. Thinking about the evolution of photosynthesis. Photosynth Res, 2004, 80: 373-386

14 Olson J M. Photosynthesis in the Archean Era. Photosynth Res, 2006 88: 109-117

15 Xiong J, Fischer W M, Inoue K, et al. Molecular evidence for the early evolution of photosynthesis. Science, 2000, 289: 1724-1730

16 Widdel F, Schnell S, Heising S, et al. Ferrous iron oxidation by anoxygenic phototrophic bacteria. Nature, 1993, 362: 834-836

17 Ehrenreich A, Widdel F. Anaerobic oxidation of ferrous iron by purple bacteria, a new type of phototrophic metabolism. Appl Environ Microbiol, 1994, 60: 4517-4526

18 Heising S, Richter L, Ludwig W, et al. Chlorobium ferrooxidans sp. nov., a phototrophic green sulfur bacterium that oxidizes ferrous iron in coculture with a "Geospirillum" sp. strain. Arch Microbiol, 1999, 172: $116-124$

19 Konhauser K O, Hamade T, Raiswell R, et al. Could bacteria have formed the Precambrian banded iron formations? Geology, 2002, 30: 1079-1082

20 Bekker A, Holland H D, Wang P L, et al. Dating the rise of atmospheric oxygen. Nature, 2004, 427: 117-120

21 Anbar A D, Duan Y, Lyons T W, et al. A whiff of oxygen before the Great Oxidation Event? Science, 2007, 317: 1903-1906

22 Garvin J, Buick R, Anbar A D, et al. Isotopic evidence for an aerobic nitrogen cycle in the latest Archean. Science, 2009, 323: 1045-1048

23 Kaufman A J, Johnston D T, Farquhar J, et al. Late Archean biospheric oxygenation and atmospheric evolution. Science, 2007, 317: 1900-1903

24 Catling D C, Claire M W. How Earth's atmosphere evolved to an oxic state: A status report. Earth Planet Sci Lett, 2005, 237: 1-20

25 Kopp R E, Kirschvink J L, Hiburn I A, et al. The Paleoproterozoic snowball earth: A climate disaster triggered by the evolution of oxygenic photosynthesis. Proc Natl Acad Sci USA, 2005, 102: 1113111136

26 Ohmoto H. When did the Earth's atmosphere become oxic? Geochem News, 1997, 93: 26-27

27 Knoll A H, Summons R E, Waldbauer J R, et al. The geological succession of primary producers in the oceans. In: Falkowski P G, Knoll A H, eds. Evolution of Primary Producers in the Sea. Burlington: Elsevier Academic Press, 2007. 133-163

28 Jiao N Z, Herndl G J, Hansell D A, et al. Microbial production of recalcitrant dissolved organic matter: Long-term carbon storage in the global ocean. Nat Rev Microbiol, 2010, 8: 593-599

29 Mittere R M. Methanogenesis and sulfate reduction in marine sediments: A new model. Earth Planet Sci Lett, 2010, 295: 358-366

30 Yoshioka H, Maruyama A, Nakamura T, et al. Activities and distribution of methanogenic and methane-oxidizing microbes in marine sediments from the Cascadia Margin. Geobiology, 2010, 8: 223-233

31 Eriksson T, Öquist M G, Nilsson M B. Production and oxidation of methane in a boreal mire after a decade of increased temperature and nitrogen and sulfur deposition. Glob Change Biol, 2010, 16: 21302144

32 Shoemaker J K, Schrag D P. Subsurface characterization of methane production and oxidation from a New Hampshire wetland. Geobiology, 2010, 8: 234-243

33 Martinson G O, Werner F A, Sherber C, et al. Methane emissions from tank bromeliads in neotropical forests. Nat Geosci, 2010, 3: 1-4

34 Boetius A, Ravenschlag K, Schubert C J, et al. A marine microbial consortium apparently mediating anaerobic oxidation of methane. Nature, 2000, 407: 623-626

35 Orphan V J, House C H, Hinrichs K U, et al. Methane-consuming Archaea revealed by directly coupled isotopic and phylogenetic analysis. Science, 2001, 293: 484-487

36 Hallam S J, Putnam N, Preston C M, et al. Reverse methanogenesis: Testing the hypothesis with environmental genomics. Science, 2004, 305: 1457-1462

37 Raghoebarsing A A, Pol A, van de Pas-Schoonen K T, et al. A microbial consortium couples anaerobic methane oxidation to denitrification. Nature, 2006, 440: 918-921 
38 Ettwig K F, Butler M K, Paslier D L, et al. Nitrite-driven anaerobic methane oxidation by oxygenic bacteria. Nature, 2010, 464: 543-548

39 Dunfield P F, Yuryev A, Senin P, et al. Methane oxidation by an extremely acidophilic bacterium of the phylum Verrucomicrobia. Nature, 2007, 450: 879-882

40 Stetter K O. Hyperthermophilic procaryotes. FEMS Microbiol Rev, 1996, 18: 149-158

41 Rabus A, Hansen T A, Widdel F. Dissimilatory sulfate- and sulfurreducing prokaryotes. In: Dworkin M, Falkow S, Rosenberg E, et al., eds. The Prokaryotes. New York: Springer, 2006. 659-768

42 Shen Y A, Buick R, Canfield D E. Isotopic evidence for microbial sulphate reduction in the early Archaean era. Nature, 2001, 410: 77-81

43 Shen Y A, Farquhar J, Masterson A, et al. Evaluating the role of microbial sulfate reduction in the early Archean using quadruple isotope systematics. Earth Planet Sci Lett, 2009, 279: 383-391

44 Habicht K S, Gade M, Thamdrup B, et al. Calibration of sulfate levels in the Archean ocean. Science, 2002, 298: 2372-2374

45 Thamdrup B, Finster K, Hansen J W, et al. Bacterial disproportionation of elemental sulfur coupled to chemical reduction of iron and manganese. Appl Environ Microbiol, 1993, 59: 101-108

46 Canfield D E, Thamdrup B. The production of ${ }^{34} \mathrm{~S}$ depleted sulfide during bacterial disproportionation of elemental sulfur. Science, 1994, 266: 1973-1975

47 Johnston D T, Wing B A, Farquhar J, et al. Active microbial sulfur disproportionation in the Mesoproterozoic. Science, 2005, 310: 1477-1479

48 Parnell J, Boyce A J, Mark D, et al. Early oxygenation of the terrestrial environment during the Mesoproterozoic. Nature, 2010, 468: 290-293

49 Wacey D, McLoughlin N, Whitehouse M J, et al. Two coexisting sulfur metabolisms in a ca. 3400 Ma sandstone. Geology, 2010, 38: 1115-1118

50 Canfield D E, Farquhar J, Zerkle A L. High isotope fractionations during sulfate reduction in a low-sulfate euxinic ocean analog. Geology, 2010, 38: 415-418

51 Wortmann U G, Bernasconi S M, Bottcher M E. Hypersulfidic deep biosphere indicates extreme sulfur isotope fractionation during single-step microbial sulfate reduction. Geology, 2001, 29: 647-650

52 Sim M S, Bosak T, Ono S H. Large sulfur isotope fractionation does not require disproportionation. Science, 2011, 333: 74-78

53 Canfield D E, Teske A. Late proterozoic rise in atmospheric oxygen concentration inferred from phylogenetic and sulphur-isotope studies. Nature, 1996, 382: 127-132

54 Brocks J J, Love G D, Summons R E, et al. Biomarker evidence for green and purple sulphur bacteria in a stratified Palaeoproterozoic sea. Nature, 2005, 437: 866-870

55 Grice K, Cao C, Love G D, et al. Photic zone euxinia during the Permian-Triassic superanoxic event. Science, 2005, 307: 706-709

56 Logan G A, Hinman M C, Walter M R, et al. Biogeochemistry of the 1640 Ma McArthur River (HYC) lead-zinc ore and host sediments, Northern Territory, Australia. Geochim Cosmochim Acta, 2001, 65: 2317-2336

57 Wakeham S G, Amann R, Freeman K H, et al. Microbial ecology of the stratified water column of the Black Sea as revealed by a comprehensive biomarker study. Org Geochem, 2007, 38: 2070-2097

58 Sorokin D Y. Diversity of halophilic sulfur-oxidizing bacteria in hypersaline habitats. In: Dahl C, Friedrich C G, eds. Microbial Sulfur Metabolism. Berlin: Springer, 2008. 225-237

59 Wacey D, Saunders M, Brasier M D, et al. Earliest microbially mediated pyrite oxidation in $~ 3.4$ billion-year-old sediments. Earth Planet Sci Lett, 2011, 301: 393-402

60 Gruber N, Galloway J N. An Earth-system perspective of the global nitrogen cycle. Nature, 2008, 451: 293-296

61 Moisander P H, Beinart R A, Hewson I, et al. Unicellular cyanobacterial distributions broaden the oceanic $\mathrm{N}_{2}$ fixation domain. Science, 2010, 327: 1512-1514

62 Zehr J P, Jenkins B D, Short S M, et al. Nitrogenase gene diversity and microbial community structure: A cross-system comparison. En- viron Microbiol, 2003, 5: 539-554

63 Barron A R, Wurzburger N, Bellenger J P, et al. Molybdenum limitation of asymbiotic nitrogen fixation in tropical forest soils. Nat Geosci, 2009, 2: 42-45

64 Severin I, Acinas S G, Stal L J. Diversity of nitrogen-fixing bacteria in cyanobacterial mats. FEMS Microbiol Ecol, 2010, 73: 514-525

65 Prosser J I, Nicol G W. Relative contributions of archaea and bacteria to aerobic ammonia oxidation in the environment. Environ Microbiol, 2008, 10: 2931-2941

66 Leininger S, Urich T, Schloter M, et al. Archaea predominate among ammonia-oxidizing prokaryotes in soils. Nature, 2006, 442: 806-809

67 Francis C A, Roberts K J, Beman J M, et al. Ubiquity and diversity of ammonia-oxidizing archaea in water columns and sediments of the ocean. Proc Natl Acad Sci USA, 2005, 102: 14683-14688

68 Zhang L M, Offre P R, He J Z, et al. Autotrophic ammonia oxidation by soil thaumarchaea. Proc Natl Acad Sci USA, 2010, 107: 1724017245

69 Pratscher J, Dumont M G, Conrad R. Ammonia oxidation coupled to $\mathrm{CO}_{2}$ fixation by archaea and bacteria in an agricultural soil. Proc Natl Acad Sci USA, 2011, 108: 4170-4175

70 Martens-Habbena W, Berube P M, Urakawa H, et al. Ammonia oxidation kinetics determine niche separation of nitrifying Archaea and Bacteria. Nature, 2009, 461: 976-979

71 Beman J M, Chow C E, King A L, et al. Global declines in oceanic nitrification rates as a consequence of ocean acidification. Proc Natl Acad Sci USA, 2011, 108: 208-213

72 Risgaard-Petersen N, Langezaal A M, Ingvardsen S, et al. Evidence for complete denitrification in a benthic foraminifer. Nature, 2006, 443: 93-96

73 Codispoti L A. An oceanic fixed nitrogen sink exceeding $400 \mathrm{Tg} \mathrm{N}$ $\mathrm{a}^{-1}$ vs the concept of homeostasis in the fixed-nitrogen inventory. Biogeosciences, 2007, 4: 233-253

74 Kuypers M M M, Lavik G, Thamdrup B. Anaerobic ammonium oxidation in the marine environment. In: Neretin L, ed. Past and Present Water Column Anoxia. Dordrecht: Springer, 2006. 311-335

75 Francis C A, Beman J M, Kuypers M M M. New processes and players in the nitrogen cycle: The microbial ecology of anaerobic and archaeal ammonia oxidation. ISME J, 2007, 1: 19-27

$76 \mathrm{Li} \mathrm{H}$, Chen S, Mu B Z, et al. Molecular detection of anaerobic ammonium-oxidizing (anammox) bacteria in high-temperature petroleum reservoirs. Microb Ecol, 2010, 60: 771-783

77 Frei R, Gaucher C, Poulton S W, et al. Fluctuations in Precambrian atmospheric oxygenation recorded by chromium isotopes. Nature, 2009, 46: 250-253

78 Bauersachs T, Speelman E N, Hopmans E C, et al. Fossilized glycolipids reveal past oceanic $\mathrm{N}_{2}$ fixation by heterocystous cyanobacteria. Proc Natl Acad Sci USA, 2010, 107: 19190-19194

79 Blankenship R, Madigan M, Bauer C. Microbiology of nitrogen fixation by anoxygenic photosynthetic bacteria. In: Govindjee J, Amesz J, Barber R E, et al., eds. Anoxygenic Photosynthetic Bacteria, 2, Advances in Photosynthesis and Respiration. Netherlands: Springer, 2004. 915-928

80 Raymond J, Siefert J L, Staples C R, et al. The natural history of nitrogen fixation. Mol Biol Evol, 2004, 21: 541-554

81 Thomazo C, Ader M, Philippot P. Extreme ${ }^{15} \mathrm{~N}$-enrichments in 2.72Gyr-old sediments: Evidence for a turning point in the nitrogen cycle. Geobiology, 2011, 9: 107-120

82 Byrne N, Strous M, Crepeau V, et al. Presence and activity of anaerobic ammonium-oxidizing bacteria at deep-sea hydrothermal vents. ISME J, 2009, 3: 117-123

83 Zerkle A L, House C H, Cox R P, et al. Metal limitation of cyanobacterial $\mathrm{N}_{2}$ fixation and implications for the Precambrian nitrogen cycle. Geobiology, 2006, 4: 285-297

84 Bazylinski D A, Frankel R B. Magnetosome formation in prokaryotes. Nat Rev Microbiol, 2004, 2: 217-230

85 Pan Y, Deng C, Liu Q, et al. Biomineralization and magnetism of bacterial magnetosomes. Chin Sci Bull, 2004, 49: 2563-2568

86 Weber K A, Achenbach L A, Coates J D. Microorganisms pumping iron: Anaerobic microbial iron oxidation and reduction. Nat Rev Mi- 
crobiol, 2006, 4: 752-764

87 Konhauser K O, Kappler A, Roden E E. Iron in microbial metabolisms. Elements, 2011, 7: 89-93

88 Kappler A, Newman D K. Formation of Fe(III)-minerals by Fe(II)oxidizing photoautotrophic bacteria. Geochim Cosmochim Acta, 2004, 68: 1217-1226

89 Kappler A, Pasquero C, Konhauser K O, et al. Deposition of banded iron formations by anoxygenic phototrophic Fe(II)-oxidizing bacteria. Geology, 2005, 33: 865-868

90 Miot J, Benzerara K, Morin G, et al. Transformation of vivianite by anaerobic nitrate-reducing iron-oxidizing bacteria. Geobiology, 2009, 7: $373-384$

91 Lovley D R, Stolz J F, Nord G L, et al. Anaerobic production of magnetite by a dissimilatory iron-reducing microorganism. Nature, 1987, 330: 252-254

92 Myers C R, Nealson K H. Bacterial manganese reduction and growth with manganese oxide as the sole electron acceptor. Science, 1988, 240: 1319-1321

93 Lovley D R, Holmes D E, Neivn K P. Dissimilatory Fe(III) and Mn(IV) reduction. Adv Microb Physiol, 2004, 49: 219-286

94 Lehours A, Rabiet M, Morel-Desrosiers N, et al. Ferric iron reduction by fermentation strain BS2 isolated from an iron-rich anoxic environmental (Lake Pavin, France). Geomicrobiol J, 2010, 27: 714722

95 Coleman M L, Hedrick D B, Lovley D R, et al. Reduction of Fe(III) in sediments by sulfate reducing bacteria. Nature, 1993, 361: 436438

$96 \mathrm{Li} \mathrm{Y,} \mathrm{Vali} \mathrm{H,} \mathrm{Sears} \mathrm{S} \mathrm{K,} \mathrm{et} \mathrm{al.} \mathrm{Iron} \mathrm{reduction} \mathrm{and} \mathrm{alteration} \mathrm{of}$ nontronite NAu-2 by a sulfate-reducing bacterium. Geochim Cosmochim Acta, 2004, 68: 3251-3260

97 Bond D R, Lovley D R. Reduction of Fe(III) oxide by methanogens in the presence and absence of extracellular quinones. Environ Microbiol, 2002, 4: 115-124

98 Liu D, Dong H, Bishop M E, et al. Reduction of structural Fe(III) in nontronite by methanogen Methanosarcina barkeri. Geochim Cosmochim Acta, 2011, 75: 1057-1071

99 Vargas M, Kashefi K, Blunt-Harris E L, et al. Microbiological evidence for Fe(III) reduction on early Earth. Nature, 1998, 395: 65-67

100 Schrenk M O, Edwards K J, Goodman R M, et al. Distribution of Thiobacillus ferrooxidans and Leptospirillum ferroxidans: Implications for generation of acid mine drainage. Science, 1998, 279: 15191522

101 Coupland K, Johnson D B. Evidence that the potential for dissimilatory ferric reduction is widespread among acidophilic heterotrophic bacteria. FEMS Microbiol Lett, 2008, 279: 30-35

102 Summons R E, Jahnke L L, Hope J M, et al. 2-Methylhopanoids as biomarkers for cyanobacterial oxygenic photosynthesis. Nature, 1999, 400: 554-557

103 Köster J, Volkman J K, Rullkötter J, et al. Mono-, di- and trimethyl-branched alkanes in cultures of the filamentous cyanobacterium Calothrix scopulorum. Org Geochem, 1999, 30: 1367-1379

104 Grice K, Schaeffer P, Schwark L, et al. Molecular indicators of palaeoenvironmental conditions in an immature Permian shale (Kupferschiefer, Lower Rhine Basin, N.W. Germany) from free and S-bound lipids. Org Geochem, 1996, 25: 131-147

105 Summons R E, Powell T G. Chlorobiaceae in Palaeozoic sea revealed by biological markers, isotopes and geology. Nature, 1986, 319: 763-765

106 Sinninghe Damsté J S, Muyzer G, Abbas B, et al. The rise of the rhizosolenid diatoms. Science, 2004, 304: 584-588

107 Holba A G, Tegelaar E W, Huizinga B J, et al. 24-norcholestanes as age-sensitive molecular fossils. Geology, 1998, 26: 783-786

108 Bianchi T S, Canuel E A. Chemical Biomarkers in Aquatic Ecosystems. Princeton: Princeton University Press, 2011

109 Niemann H, Lösekann T, de Beer D, et al. Novel microbial communities of the Haakon Mosby mud volcano and their role as a methane sink. Nature, 2006, 443: 854-858

110 Blumenberg M, Seifert R, Reitner J, et al. Membrane lipid patterns typify distinct anaerobic methanotrophic consortia. Proc Natl Acad
Sci USA, 2004, 101: 11111-11116

111 Cvejic J H, Bodrossy L, Kovács K L, et al. Bacterial triterpenoids of the hopane series from the methanotrophic bacteria Methylocaldum spp: Phylogenetic implications and first evidence for an unsaturated aminobacteriohopanepolyol. FEMS Microbiol Lett, 2000, 182: 361365

112 Whitcar M J, Faber E, Schoell M. Biogenic methane formation in marine and freshwater environments: $\mathrm{CO}_{2}$ reduction vs. acetate fermentation-isotope evidence. Geochim Cosmochim Acta, 1986, 50: 693-709

113 Conti S, Artoni A, Piola G. Seep-carbonates in a thrust-related anticline at the leading edge of an orogenic wedge: The case of the middle-late Miocene Salsomaggiore Ridge (Northern Apennines, Italy). Sediment Geol, 2007, 199: 233-251

114 Jiang G Q, Kennedy M J, Christie-Blick N. Stable isotopic evidence for methane seeps in Neoproterozoic postglacial cap carbonates. Nature, 2003, 426: 822-826

115 Wang J S, Jiang G Q, Xiao S H, et al. Carbon isotope evidence for widespread methane seeps in the ca. 635 Ma Doushantuo cap carbonate in south China. Geology, 2008, 36: 347-350

116 Rasmussen B. Filamentous microfossils in a 3235-million-year-old volcanogenic massive sulphide deposit. Nature, 2000, 405: 676-679

117 Zhang C L, Li Y L, Wall J D, et al. Lipid and carbon isotopic evidence of methane-oxidizing and sulfate-reducing bacteria in association with gas hydrates from the Gulf of Mexico. Geology, 2002, 30: 239-242

118 Wilkin R T, Barnes H L. Formation processes of framboidal pyrite. Geochim Cosmochim Acta, 1997, 61: 323-339

119 Wilkin R T, Arthur M A, Dean W E. History of water-column anoxia in the Black Sea indicated by pyrite framboid size distributions. Earth Planet Sci Lett, 1997, 148: 517-525

120 Sarkar A, Chakraborty P P, Mishra B, et al. Mesoproterozoic sulphidic ocean, delayed oxygenation and evolution of early life: Sulphur isotope clues from Indian Proterozoic basins. Geol Magaz, 2010, 147: 206-218

121 Farquhar J, Johnston D T, Wing B A, et al. Multiple sulphur isotopic interpretations of biosynthetic pathways: Implications for biological signatures in the sulphur isotope record. Geobiology, 2003, 1: 27-36

122 Johnston D T, Farquhar J, Wing B A, et al. Multiple sulfur isotope fractionations in biological systems: A case study with sulfate reducers and sulfur disproportionators. Am J Sci, 2005, 305: 645-660

123 Talbot H M, Summons R E, Jahuke L L, et al. Cyanobacterial bacteriohopanepolyol signatures from cultures and natural environmental settings. Org Geochem, 2008, 39: 232-263

124 Kuypers M M M, Blokker P, Erbacher J, et al. Massive expansion of marine archaea during a mid-Cretaceous oceanic anoxic event. Science, 2001, 293: 92-94

125 Sinninghe Damsté J S, Schouten S, Hopmans E C, et al. Crenarchaeol: the characteristic core glycerol dibiphytanyl glycerol tetraether membrane lipid of cosmopolitan pelagic crenarchaeota. J Lipid Res, 2002, 43: 1641-1651

126 Liu Z H, Pagani M, Zinniker D, et al. Global cooling during the Eocene-Oligocene climate transition. Science, 2009, 323: 1187-1190

127 Sinninghe Damsté J S, Strous M, Rijpstra W I C, et al. Linearly concatenated cyclobutane lipids form a dense bacterial membrane. Nature, 2002, 419: 708-712

128 Jaeschke A, Ziegler M, Hopmans E C, et al. Molecular fossil evidence for anaerobic ammonium oxidation in the Arabian Sea over the last glacial cycle. Paleoceanography, 2009, 24: PA2202

129 Kuypers M M M, van Breugel Y, Schouten S, et al. $\mathrm{N}_{2}$-fixing cyanobacteria supplied nutrient $\mathrm{N}$ for Cretaceous oceanic anoxic events. Geology, 2004, 32: 853-856

130 Luo G, Wang Y, Algeo T J, et al. Enhanced nitrogen fixation in the immediate aftermath of the latest Permian marine mass extinction. Geology, 2011, 39: 647-650

131 Xie S, Pancost R D, Yin H, et al. Two episodes of microbial change coupled with Permo/Triassic faunal mass extinction. Nature, 2005, 434: 494-497

132 Meyers P A, Bernasconi S M, Yum J G. 20 My of nitrogen fixation 
during deposition of mid-Cretaceous black shales on the Demerara Rise, equatorial Atlantic Ocean. Org Geochem, 2009, 40: 158-166

133 Zhang C L, Li Y, Ye Q, et al. Carbon isotope signatures of fatty acids in Geobacter metallireducens and Shewanella algae. Chem Geol, 2003, 195: 17-28

134 Bazylinski D A, Schübbe S. Controlled biomineralization by and applications of magnetotactic bacteria. Adv Appl Microbiol, 2007, 62: 21-62

135 Perez-Gonzalez T, Jimenez-Lopez C, Neal A L, et al. Magnetite biomineralization induced by Shewanella oneidensis. Geochim Cosmochim Acta, 2010, 74: 967-979

136 Li Y, Pfiffner S M, Dyar M D, et al. Degeneration of biogenic superparamagnetic magnetite. Geobiology, 2009, 7: 25-34

137 Kukkadapu R K, Zachara J M, Fredrickson J K, et al. Ferrous hydroxyl carbonate is a stable transformation product of biogenic magnetite. Am Mineral, 2005, 90: 510-515

138 Carvallo C, Sainctavit P, Arrio M, et al. Biogenic vs. abiogenic magnetite nanoparticles: A XMCD study. Am Mineral, 2008, 93: $880-885$

139 Dong H, Jaisi D P, Kim J, et al. Microbe-clay mineral interactions. Am Mineral, 2009, 94: 1505-1519

140 Vorhies J S, Gaines R R. Microbial dissolution of clay minerals as source of iron and silica in marine sediments. Nat Geosci, 2009, 2: 221-225

141 Sanz-Montero M, Rodriguez-Aranda J P, Pérez-Soba C. Microbial weathering of Fe-rich phyllosilicates and formation of pyrite in the dolomite precipitating environment of a Miocene lacustrine system. Eur J Mineral, 2009, 21: 163-175

142 Croal L R, Johnson C M, Beard B L, et al. Iron isotope fractionation by $\mathrm{Fe}(\mathrm{II})$-oxidizing photoautotrophic bacteria. Geochim Cosmochim Acta, 2004, 68: 1227-1242

143 Johnson C M, Beard B L, Klein C, et al. Iron isotopes constrain biologic and abiologic processes in banded iron formation genesis. Geochim Cosmochim Acta, 2008, 72: 151-169

144 Kappler A, Johnson C M, Croby H A, et al. Evidence for equilibrium iron isotope fractionation by nitrate-reducing iron(II)-oxidizing bacteria. Geochim Cosmochim Acta, 2010, 74: 2826-2842

145 Crosby H A, Johnson C M, Roden E E, et al. Coupled Fe(II)-Fe(III) electron and atom exchange as a mechanism for Fe isotope fractionation during dissimilatory iron oxide reduction. Environ Sci Technol, 2005, 39: 6698-6704

146 Grzebyk D, Schofield O, Vetriani C, et al. The Mesozoic radiation of Eukaryotic algae: The portable plastid hypothesis. J Phycol, 2003, 39: 259-267

147 Raghoebarsing A A, Smolders A J P, Schmid M C, et al. Methanotrophic symbionts provide carbon for photosynthesis in peat bogs. Nature, 2005, 436: 1153-1156

148 Kip N, van Winden J F, Pan Y, et al. Global prevalence of methane oxidation by symbiotic bacteria in peat-moss ecosystems. Nat Geosci, 2010, 3: 617-621

149 Rydin H, Gunnarsson U, Sundberg S. The role of Sphagnum in peatland development and persistence. In: Wieder R K, Vitt D H, eds. Boreal Peatland Ecosystems. New York: Springer, 2006. 47

150 MacDonald G M, Beilman D W, Kremenetski K V, et al. Rapid early development of circumarctic peatlands and atmospheric $\mathrm{CH}_{4}$ and $\mathrm{CO}_{2}$ variations. Science, 2006, 314: 285-288

151 Jones M C, Yu Z C. Rapid deglacial and early Holocene expansion of peatlands in Alaska. Proc Natl Acad Sci USA, 2010, 107: 73477352

152 Kennett J P, Cannariato K G, Hendy I L, et al. Carbon isotopic evidence for methane hydrate instability during Quaternary interstadials. Science, 2000, 288: 128-133

153 Hinrichs K U, Hmelo L R, Sylva S P. Molecular fossil record of elevated methane levels in Late Pleistocene coastal waters. Science, 2003, 299: 1214-1217

154 de Garidel-Thoron T, Beaufort L, Bassinot F, et al. Evidence for large methane releases to the atmosphere from deep-sea gas-hydrate dissociation during the last glacial episode. Proc Natl Acad Sci USA, 2004, 101: 9187-9192
155 Ruddiman W F, Guo Z T, Zhou X, et al. Early rice farming and anomalous methane trends. Quat Sci Rev, 2008, 27: 1291-1295

156 van Winden J F, Kip N, Reichart G-J, et al. Lipids of symbiotic methane-oxidizing bacteria in peat moss studied using stable carbon isotope labeling. Org Geochem, 2010, 41: 1040-1044

157 Chen Y, Murrell J C. Geomicrobiology: Methanotrophs in moss. Nat Geosci, 2010, 3: 595-596

158 Bristow T F, Bonifacie M, Derkowsk A, et al. A hydrothermal origin for isotopically anomalous cap dolostone cements from south China. Nature, 2011, 474: 68-71

159 Tripati A, Elderfield H. Deep-sea temperature and circulation changes at the Paleocene-Eocene Thermal Maximum. Science, 2005, 308: 1894-1898

160 Sluijs A, Schouten S, Pagani M, et al. Subtropical Arctic Ocean temperatures during the Palaeocene/Eocene Thermal Maximum. Nature, 2006, 441: 610-613

161 Jenkyns H C. Evidence for rapid climate change in the MesozoicPalaeogene greenhouse world. Philios Trans R Soc Lond A, 2003, 361: 1885-1916

162 Pagani M, Calderia K, Archer D, et al. An ancient carbon mystery. Science, 2006, 314: 1556-1557

163 Zeebe R E, Zachos J C, Dickens G R. Carbon dioxide forcing alone insufficient to explain Palaeocene-Eocene Thermal Maximum warming. Nat Geosci, 2009, 2: 1-5

164 Pancost R D, Steart D S, Handley L, et al. Increased terrestrial methane cycling at the Palaeocene-Eocene thermal maximum. Nature, 2007, 449: 232-235

165 Xie S, Pancost R D, Huang J, et al. Changes in the global carbon cycle occurred as two episodes during the Permian-Triassic crisis. Geology, 2007, 35: 1083-1086

166 Wignall P B, Sun Y D, Bond D P G, et al. Volcanism, mass extinction, and carbon isotope fluctuations in the Middle Permian of China. Science, 2009, 324: 1179-1182

167 Stanley S M. Relation of Phanerozoic stable isotope excursions to climate, bacterial metabolism, and major extinctions. Proc Natl Acad Sci USA, 2010, 107: 19185-19189

168 Luo G, Huang J, Xie S, et al. Relationships between carbon isotope evolution and variation of microbes during the Permian-Triassic transition at Meishan Section, South China. Int J Earth Sci, 2010, 99: 775-784

169 Canfield D E. A new model for Proterozoic ocean chemistry. Nature, 1998, 396: 450-453

170 Poulton S W, Fralick P W, Canfield D E. The transition to a sulphidic ocean $~ 1.84$ billion years ago. Nature, 2004, 431: 173-177

171 Gill B C, Lyons T W, Young S A, et al. Geochemical evidence for widespread euxinia in the Later Cambrian ocean. Nature, 2011, 469: $80-83$

172 Armstrong H A, Abbott G D, Turner B R, et al. Black shale deposition in an Upper Ordovician-Silurian permanently stratified, periglacial basin, southern Jordan. Palaeogeogr Palaeoclima Palaeoecol, 2009, 273: 368-377

173 Marynowski L, Filipiak P. Water column euxinia and wildfire evidence during deposition of the Upper Famennian Hangenberg event horizon from the Holy Cross Mountains (central Poland). Geol Magaz, 2007, 144: 569-595

174 Cao C, Love G D, Hays L E, et al. Biogeochemical evidence for euxinic oceans and ecological disturbance presaging the end-Permian mass extinction event. Earth Planet Sci Lett, 2009, 281: 188-201

175 van Bentum E C, Hetzel A, Brumsack H-J, et al. Reconstruction of water column anoxia in the equatorial Atlantic during the Cenomanian-Turonian oceanic anoxic event using biomarker and trace metal proxies. Palaeogeogr Palaeoclima Palaeoecol, 2009, 280: 489-498

176 Luo G, Kump L R, Wang Y, et al. Isotopic evidence for an anomalously low oceanic sulphate concentration following end-Permian mass extinction. Earth Planet Sci Lett, 2010, 300: 101-111

177 Schulz H N, Brinkhoff T, Ferdelman T G, et al. Dense populations of a giant sulfur bacterium in Namibian shelf sediments. Science, 1999, 284: 493-495

178 Kuypers M M M, Sliekers A O, Lavik G, et al. Anaerobic ammoni- 
um oxidation by anammox bacteria in the Black Sea. Nature, 2003, 422: 608-611

179 Jenkyns H C, Matthews A, Tsikos H, et al. Nitrate reduction, sulfate reduction, and sedimentary iron isotope evolution during the Cenomanian-Turonian oceanic anoxic event. Paleoceanography, 2007, 22: $1-17$

180 Kuypers M M M, Blokker P, Erbacher J, et al. Massive expansion of marine archaea during a Mid-Cretaceous oceanic anoxic event. Science, 2001, 293: 92-94

181 Okano K, Sawada K, Takashima R, et al. Further examples of archaeal-derived hydrocarbons in mid-Cretaceous Oceanic Anoxic Event (OAE) 1b sediments. Org Geochem, 2008, 39: 1088-1091

182 Kah L C, Lyons T W, Frank T D. Low marine sulphate and protracted oxygenation of the Proterozoic biosphere. Nature, 2004, 431: 834-838

183 Lowenstein T K, Hardie L A, Timofeeff M N, et al. Secular variation in seawater chemistry and the origin of calcium chloride basinal brines. Geology, 2003, 31: 857-860

184 Newton R J, Reeves E P, Kafousia N, et al. Low marine sulfate concentrations and the isolation of the European epicontinental sea during the Early Jurassic. Geology, 2011, 39: 7-10

185 Canfield D E, Farquhar J. Animal evolution, bioturbation, and the sulfate concentration of the oceans. Proc Natl Acad Sci USA, 2009, 106: 8123-8127

186 Scholten J C M, Bodegom P M, Vogelaar J, et al. Effect of sulfate and nitrate on acetate conversion by anaerobic microorganisms in a freshwater sediment. FEMS Microbiol Ecol, 2002, 42: 375-385

187 Jørgensen B B. Mineralization of organic matter in the sea bed-the role of sulphate reduction. Nature, 1982, 296: 643-645

188 Valentine D L. Biogeochemistry and microbial ecology of methane oxidation in anoxic environments: A review. Anton Leeuw, 2002, 81: 271-282

189 Ventura G T, Kenig F, Reddy C M, et al. Molecular evidence of Late Archean archaea and the presence of a subsurface hydrothermal biosphere. Proc Natl Acad Sci USA, 2007, 104: 14260-14265

190 Li C, Love G D, Lyons T W, et al. A stratified redox model for the Ediacaran Ocean. Science, 2010, 328: 80-83

191 Poulton S W, Fralick P W, Canfield D E. Spatial variability in oceanic redox structure 1.8 billion years ago. Nat Geosci, 2010, 3: 486-490

192 Hurtgen M T, Pruss S B, Knoll A H. Evaluating the relationship between the carbon and sulfur cycles in the later Cambrian ocean: An example from the Port au Port Group, western Newfoundland, Canada. Earth Planet Sci Lett, 2009, 281: 288-297

193 Canfield D E, Glazer A N, Falkowski P G. The evolution and future of Earth nitrogen cycle. Science, 2010, 330: 192-196

194 Castro H, Ogram A, Reddy K R. Phylogenetic Characterization of Methanogenic Assemblages in Eutrophic and Oligotrophic Areas of the Florida Everglades. Appl Environ Microbiol, 2004, 70: 6559-6568
195 Zehr J P, Kudela R M. Nitrogen cycle of the open ocean: From genes to ecosystems. Annu Rev Mar Sci, 2011, 3: 197-225

196 Mahaffey C, Michaels A F, Capone D G. The conundrum of marine $\mathrm{N}_{2}$ fixation. Am J Sci, 2005, 305: 546-595

197 Moore M C, Mills M M, Achterberg E P, et al. Large-scale distribution of Atlantic nitrogen fixation controlled by iron availability. Nat Geosci, 2009, 2: 867-871

198 Saito M A, Bertrand E M, Dutkiewicz S, et al. Iron conservation by reduction of metalloenzyme inventories in the marine diazotroph Crocosphaera watsonii. Proc Natl Acad Sci USA, 2011, 108: 21842189

199 Deutsch C, Sarmiento J L, Sigman D M, et al. Spatial coupling of nitrogen inputs and losses in the ocean. Nature, 2007, 445: 163-167

200 Levitan O, Rosenberg G, Setlik I, et al. Elevated $\mathrm{CO}_{2}$ enhances nitrogen fixation and growth in the marine cyanobacterium Trichodesmium. Glob Change Biol, 2007, 13: 531-538

201 Xie S, Pancost R D, Wang Y, et al. Cyanobacterial blooms tied to volcanism during the 5 m.y. Permo-Triassic biotic crisis. Geology, 2010, 38: 447-450

202 Shi D, Xu Y, Hopkinson B M, et al. Effect of ocean acidification on iron availability to marine phytoplankton. Science, 2010, 327: 676679

203 Mort H P, Adatte T, Follmi K B, et al. Phosphorus and the roles of productivity and nutrient recycling during oceanic anoxic event 2 . Geology, 2007, 35: 483-486

204 Lehmann B, Nagler T F, Holland H D, et al. Highly metalliferous carbonaceous shale and Early Cambrian seawater. Geology, 2007, 35: 403-406

205 Klein C. Some Precambrian banded iron-formations (BIFs) from around the world: Their age, geological setting, mineralogy, metamorphism, geochemistry, and origin. Amer Mineral, 2005, 90: 14731499

206 Canfield D E, Habicht K S, Thamdrup B. The Archean sulfur cycle and the early history of atmospheric oxygen. Nature, 2000, 288: 658661

207 Holland $\mathrm{H}$. The oxygenation of the atmosphere and oceans. Philos Trans R Soc Lond B, 2006, 361: 903-915

208 Posth N R, Hegler F, Konhauser K O, et al. Alternating Si and Fe deposition caused by temperature fluctuations in Precambrian oceans. Nat Geosci, 2008, 1: 703-708

209 Konhauser K O, Amskold L, Lalonde S V, et al. Decoupling photochemical Fe(II) oxidation from shallow-water BIF deposition. Earth Planet Sci Lett, 2007, 258: 87-100

210 Planavsky N, Rouxel O, Bekker A, et al. Iron-oxidizing microbial ecosystems thrived in late Paleoproterozoic redox-stratified oceans. Earth Planet Sci Lett, 2009, 286: 230-242

211 Li Y, Konhauser K O, Cole D R, et al. Mineral ecophysiological data provide growing evidence for microbial activity in banded-iron formations. Geology, 2011, 29: 707-710

Open Access This article is distributed under the terms of the Creative Commons Attribution License which permits any use, distribution, and reproduction in any medium, provided the original author(s) and source are credited. 